\title{
Sentiment Volatility and Bank Lending Behavior
}

\author{
January 18, 2016
}

\begin{abstract}
Using a panel of commercial, co-operative and savings banks from G7 countries, we investigate whether the changes in sentiment and its volatility affect banks' lending behavior. We show that the changes in economic agents' sentiment and its volatility affect bank lending negatively, while the impact sizes differ across indicators. We also find that the impact of volatility effects on banks' loan growth varies at excessive levels. We highlight the role of several bank-specific characteristics in transmission of uncertainty effects on the growth of bank loans, as uncertainty affects extenuate or mitigate through them.
\end{abstract}

Keywords: Bank loans, tier 1 capital, business sentiment, consumer sentiment, leading indicators, uncertainty

JEL classification: C22, C23, D81, E51. 


\section{Introduction}

Although, due to the developments in the financial markets, some economists suggest that bank lending may not be as important as it used to be, many argue that banks do play a key role as they specialize in overcoming frictions in the credit market by acquiring costly information on borrowers. To that end, research has shown that reductions in loanable funds could have a major impact on bank-dependent borrowers (e.g., small businesses) and may cause substantial reductions in their fixed investment expenditures or even lead them to bankruptcy (e.g., Berger and Udell, 2002; Ivashina and Scharfstein, 2010 and Ferri et al., 2014). Hence, it is not surprising that researchers have begun to examine the factors that affect banks' lending behavior with a renewed attention following the 2008 financial crisis, as the repercussions of this crisis affected many developed and emerging countries throughout the globe.

In this paper, different from the literature, we investigate to what extent the level and the volatility of economic agents' sentiment affect banks' lending behavior. Sentiment indicators, which gauge the state of the economy from the perspective of the economic agents, are widely considered as a critical component by academics, policy makers and media in the transmission of shocks into the economic activity (e.g., Barsky and Sims, 2012; Bachmann and Sims, 2012; Delis et al., 2014). We also know that leading indicators usually change before the economic activities change as a whole and provide useful information on the state of the economy. Surprisingly, earlier studies have not examined the impact of the level and volatility of economic agents sentiment on banks' lending behavior. ${ }^{1}$ As each type of agent acts on a specific set of (imperfect) information that emanate from the state of the economy, rational inattention, or their own asymmetric goals and strategies, it is important find out whether bank managers respond to changes and variability in sentiment.

In our study, we also consider the possibility of asymmetric effects of sentiment volatil-

\footnotetext{
${ }^{1}$ Only Delis et al. (2014) has examined the lending behavior of the US banks during periods of anxiety. They measured anxiety based on changes in economic agents' confidence levels.
} 
ity on banks' credit growth. Identifying distinct periods of excessive volatility levels perceived by each type of economic agent we examine whether banks' lending behavior changes during episodes of extreme volatility. Figure 1 plots the time series graph of sentiment and its volatility for all three measures for each country in our dataset. ${ }^{2}$ An inspection of these graphs show that while there are considerable similarities among the level and volatility of the sentiment measures within a country, there are considerable differences across countries. We also see that volatility series exhibit extreme variation over time, which we examine in our analysis. ${ }^{3}$

While carrying out the analysis, we control for the heterogeneous characteristics of banks' balance-sheet that relate to banks' funding strategy, capitalization, liquidity, loan quality, earning quality and size. As the Basel Accord highlights its importance, we examine the role of high quality bank capital on loan growth. Furthermore, our model contains several interaction terms between volatility and bank characteristics so that we can investigate whether volatility affects bank loans through bank-specific variables which are noted to play an important role in banks' lending behavior. Last but not the least, we control for the state of the economy by incorporating the GDP growth rate and the interest rate in our empirical models.

To carry out our investigation, we construct a large panel of commercial, co-operative, and savings banks collected from the Bankscope database for the G7 countries including Canada, Germany, France, the UK, Italy, Japan, and the US. This database provides detailed bank-level information yet the sample size is constrained due to the fact that we seek to examine the role of Core Tier 1 capital on banks' lending. The final dataset that we employ in our analysis is comprised of more than 9,000 banks and retains bank, country and time dimensions. The analysis covers the period between 1999-2014.

Our findings can be summarized as follows. We find that banks curtail their lending in response to an increase in sentiment volatility as well as to changes in sentiment. We also find that the impact size of volatility effects (which could be as high as 13\%) is

\footnotetext{
${ }^{2}$ Business sentiment indicator is not available for Canada.

${ }^{3}$ From here on, we use uncertainty and volatility interchangeably.
} 
much stronger than the impact size of changes in sentiment (which is less than 1\%). Furthermore, it turns out that the volatility effects emanating from business sentiment has the least impact (around 2\%) and that emanating from the consumer sentiment is the highest at around (13\%). When we consider the effects of excessive volatility, we see that volatility emanating from both leading indicator and business sentiment causes further reductions in loan growth. Interestingly, when consumer sentiment volatility reaches excessive levels, although the total effect of volatility on loan growth is still negative, its impact dampens to some extent. Taken together our empirical results suggest that banks' lending behavior is affected by agents' expectations.

Furthermore, we highlight the role of various bank-specific characteristics in transmission of uncertainty on the growth of bank loans. Consistent with the common perception, we find that increased volatility leads to a drop in loan growth for banks that carry more problem loans. That is banks with bad loan portfolios curb their lending more rigorously in periods of turmoil as they are more exposed to credit risk. We also find that although banks with low return-on-asset expand their loan growth faster, it is the high return banks that can continue to expand their loans in periods of high volatility. Regarding the bank size, our results show that smaller banks are more aggressive in extending their customer base and seizing new lending opportunities, especially when there is excessive uncertainty which arise from the leading indicators. Last, as expected we find that high quality of bank funding strategy (i.e., Tier 1 bank capital) and liquidity are both crucial for credit growth. However, these two variables do not mitigate the adverse impact of uncertainty on bank lending behavior. Finally, we present a visual portrayal of uncertainty effects on new bank loans. Although the impact size of uncertainty plotted in these graphs may purely reflect the average of bank specific variables, the trend that emerges in these figures is informative with respect to the transmission of uncertainty effects through bank specific variables. In particular, these figures show that the uncertainty effects vary as the underlying bank characteristics changes.

The paper is organized as follows. Section 2 discusses the related literature. Section 
3 presents our formal empirical model. Section 4 discusses the data and the uncertainty measures. Section 5 reports the empirical results as well as the robustness checks. Section 6 concludes the paper.

\section{Related Literature}

There is a deepening literature on bank lending behavior, as banks play a vital role in a country's economic development and growth. In particular, following the great financial crisis, several researchers have begun to examine the interrelations between risk and bank lending behavior. For example, Altunbas et al. (2010) found that banks with lower expected default frequency were able to offer a larger amount of credit and protect their loan supply from changes in monetary policy. Delis et al. (2014) examined the lending behavior of US banks during periods of anxiety. They defined periods of anxiety from the perspective of consumers, firms and market analysts, according to their perceptions and expectations on future economic conditions. Their empirical results showed that when consumers' and analysts' anxiety increases, banks' total loans decline, and that this effect is more pronounced when banks hold a higher level of credit risk, and in periods of anxiety that were followed by recessions. Kosak et al. (2015) used a cross-country bank panel to test whether the quality of bank capital mattered for loan growth during the 2008 financial crisis. They found that the availability of high quality funds (tier 1 capital and retail deposits) and government support were crucial in continuous bank lending during the crisis periods.

Another strand of literature has focused on the role of bank ownership on banks' cyclical lending behavior over the business cycle. This literature provides mixed findings on the importance of ownership in times of crises. Iannotta et al. (2007) found no difference in the cyclical pattern of lending between government-owned and private banks. Cull and Martínez Pería (2013) showed that state banks in Latin America lend counter-cyclically, whereas the state banks in Eastern Europe do not. In contrast, Gam- 
bacorta and Marques-Ibanez (2011), Brei and Schclarek (2013) and Brei et al. (2013) found evidence that government-owned banks increase their lending during crises relative to normal times, while private banks' lending decreases. Thus, they argued that governments can indirectly play an active counter-cyclical role in their financial markets. Ferri et al. (2014) suggested that, irrespective of the state of the economy or the financial markets, stakeholder banks attempt to smooth financial conditions for their customers to maintain longer term borrower-lender relationship by conducting less procyclical loan supply polices. Bertay et al. (2015) showed that lending by state banks is less procyclical than lending by private banks, especially if the bank is located in a country with good governance.

When we sift through the literature, we identify a number of studies which examine bank lending behavior during the recent financial crisis using loan-level data. For instance, Puri et al. (2011) studied retail banks' lending in Germany and found an overall reduction in demand for consumer loans as well as a significant contraction in the supply of loans following the US financial crisis. According to Ivashina and Scharfstein (2010), new lending across all types of loan categories declined substantially during the 2008 financial crisis. They showed that part of this decline could be explained by a drop in demand as firms scaled back their expansion plans, and other part may be attributed to the reduction in the supply of loans, especially for banks with less access to deposits, as well as to banks' desire to curtail their credit-line drawdowns due to increased risks in this period.

In addition, a number of studies examined the impact of macroeconomic uncertainty on the cross-sectional dispersion of bank loans. Baum et al. (2009) showed for a large panel of US banks that macroeconomic uncertainty has a negative effect on the crosssectional dispersion of total-loans-to-assets ratio and argued that uncertainty distorts the efficient allocation of scarce bank resources. They claim that uncertainty affects bank managers ability to predict returns from available lending opportunities and as a consequence act more conservatively while they cut back on loans. Following Baum 
et al. (2009), Quagliariello (2009), using a large panel of banks in Italy, and Calmès and Théoret (2014), examining the largest 6 banks from Canada and 20 banks from the US, arrived at similar conclusions.

In the main, our study contributes to the literature on the determinants of banks' lending behavior, as we scrutinize the role of sentiment that emanate from businesses, consumers, and leading indicators. First, focusing our attention on the G7 countries' commercial, co-operative, and savings banks, we examine both the level and volatility effects of business sentiment, consumer sentiment, and the leading economic indicator on banks' lending activities. Secondly, to examine the asymmetric effects of sentiment volatility, we scrutinize how credit growth changes during episodes of extreme volatility. Furthermore, we test to what extent volatility affects bank loans through its impact on various bank-specific characteristics. In our analysis, we control for macroeconomic factors that may effect bank lending behavior.

\section{Methodology}

In what follows, we first present a naïve model where we only allow for bank-level and macroeconomic control variables to explain banks' loan growth. Next, we augment our basic model by introducing the variables that capture the changes in the level and volatility of sentiment. Finally, we examine how credit growth changes during episodes of extreme volatility to examine the asymmetric effects sentiment volatility. Table 1 provides the descriptives of the variables used in our models.

\subsection{Basic bank lending model}

Our basic model assumes that a bank's ability and propensity to increase its loan supply depend both on its own characteristics and on the environment within which it operates:

$$
\Delta \ln \left(\text { loans }_{i, t}\right)=\alpha+\gamma \boldsymbol{X}_{\boldsymbol{i}, \boldsymbol{t}-\mathbf{1}}+\boldsymbol{\phi} \text { MacroControl }_{\boldsymbol{j}, \boldsymbol{t}-\mathbf{1}}+\nu_{i}+\text { year }_{t}+\epsilon_{i, t}
$$


The dependent variable, $\Delta \ln ($ loans), captures the loan growth of bank $i$ at time $t$; $\boldsymbol{X}$ is a vector of bank-level explanatory variables that captures bank characteristics; MacroControl is a vector of macroeconomic control variables for country; $\nu_{i}$ captures banks fixed effects, year ${ }_{t}$ denote year dummies, and $\epsilon_{i, t}$ is the error term.

For robustness purposes, we carry out the analysis for the changes in net-loan growth $\left(\Delta l n_{-} N L\right)$ and that in gross-loan growth $\left(\Delta l n_{-} G L\right)$. As explanatory variables, the model embodies several bank-level variables that earlier research has shown to play an important role in determination of loan supply. Firstly, we should stress that our model incorporates a variable that captures high quality funding sources. Although, in line with the Basel Accords researchers generally employ equity-to-total-asset ratio to account for banks' solvency, we use Tier 1 regulatory capital ratio, (Tier 1$)$, in our model, ${ }^{4}$ as a broader measure of regulatory capital. ${ }^{5}$ This measure, has the highest loss-absorbtion capacity, and we expect to find that Tier 1 capital will have a positive effect on credit growth (Kosak et al., 2015).

Our second variable captures the quality of banks' loan portfolio as we measure the extent of total loans that are impaired or doubtful (Impaired_GL). This variable is shown to play an important role in bank managers' lending decisions, especially during periods of uncertainty (e.g., Brewer et al., 2014; Delis et al., 2014). To that end, if a bank holds a relatively risky portfolio, then the bank managers might behave more conservatively in issuing new loans, while other banks might have the latitude to lend more if their portfolios are less risky. Hence, we expect a negative relationship between the level of bad loans and loan growth. Furthermore, we use the natural logarithm of bank's total assets (Size) as a proxy to measure the effect of bank size on loan growth. We predict a negative sign here, as smaller banks tend to expand loans more aggressively (e.g., Delis et al., 2014; Bertay et al., 2015).

\footnotetext{
${ }^{4}$ Under Basel III, there is a narrower definition of Tier 1 regulatory capital. For example, common equity (e.g., retained earnings, share premium reserves) will continue to qualify as core Tier 1 capital, but other hybrid capital instruments will be replaced by instruments that are more loss-absorbing.

${ }^{5}$ See for example, De Haas and Van Lelyveld (2010); Delis et al. (2014) who argued that wellcapitalized banks can better protect their lending from monetary policy shocks.
} 
Our model also contains return-on-total-average-asset $(R O A A)$ as a proxy to reflect banks' earning quality, efficiency and operational performance. Although we do not have a strong view on the sign of this variable, one may expect a negative effect, as more profitable banks are expected to have a more rigorous reviewing process and to have less interest in increasing 'marginal' and lower quality lending (Tennant and Sutherland, 2014).

Lastly, we incorporate a measure of bank liquidity in our model, a variable which is often considered to have an important influence on banks' lending behavior (e.g., Kashyap and Stein, 2000; Ferri et al., 2014). We use the ratio of liquid assets on total customer deposits and other short-term borrowing (Liquid_Tdb) as a proxy to gauge banks' liquidity. ${ }^{6}$ We predict that more liquid banks will be able to lend more as compared to illiquid banks.

We collect two macroeconomic control variables from the Datastream database for G7 countries. These are the GDP growth rate $(\triangle G D P)$ and the long-term interest rates $(I R) .{ }^{7}$ We expect that GDP growth will have a positive impact on loan growth whereas interest rates will have a negative impact.

\subsection{Examining the role of the level and volatility of sentiment}

Given that the changes in an economy will be reflected in economic agents' views, we use sentiment indicators as a proxy to capture the swings in beliefs of consumers and business leaders. ${ }^{8}$ Using three different sentiment indicators, namely, business and consumer sentiment indicators as well as the leading indicator which capture the aggregated views of the businesses, consumers on the economic outlook, we examine to what extent the changes and the volatility of sentiment that emanate from any of these sources affect bank lending. To do so, we incorporate changes in sentiment and sentiment volatility per

\footnotetext{
${ }^{6}$ Liquid assets include cash, government bonds, short-term claims on other banks (including certificates of deposit).

${ }^{7}$ Long-term interest rates refer to government bonds with a residual maturity of about ten years.

${ }^{8}$ It is widely acknowledged that sentiment plays an important role in the transmission of shocks into the economy (e.g., Barsky and Sims, 2012; Bachmann and Sims, 2012; Delis et al., 2014).
} 
each source into our model as follows:

$$
\begin{aligned}
\Delta \ln \left(\text { loans }_{i, t}\right) & =\alpha+\gamma \boldsymbol{X}_{\boldsymbol{i}, t-1}+\boldsymbol{\lambda} \boldsymbol{\Delta} \text { Sent }_{j, t-1}+\boldsymbol{\beta} \hat{\boldsymbol{\sigma}}_{\text {Sent }_{j, t-1}}+\boldsymbol{\delta}\left(\hat{\boldsymbol{\sigma}}_{\text {Sent }_{j, t-1}} \times \boldsymbol{X}_{\boldsymbol{i , t - 1} \mathbf{1}}\right) \\
& +\phi \text { MacroControl }_{j, t-1}+\nu_{i}+\text { year }_{t}+\epsilon_{i t}
\end{aligned}
$$

where $\boldsymbol{\Delta} \boldsymbol{S e n t}_{\boldsymbol{j}}$ and $\hat{\boldsymbol{\sigma}}_{\boldsymbol{S e n t}_{\boldsymbol{j}}}$ is a vector of changes and volatilities of sentiment emanating from three different sources in each country, respectively. We do not have a strong view on the sign of the coefficient that relates changes in sentiment, as banks may consider increasing or reducing their loanable funds when economic agents' perception on the general economic conditions improves. For example, bank managers may see that positive changes in sentiment as heating up of the economy, which may render monetary policy authorities to raise interest rates in anticipation of higher inflation in the future. In such circumstances, bank managers may be reluctant to extend credit due to balance sheet effects that may emerge in the future. On the contrary, a positive change of the sentiment indicators may initiate a new round of lending, as the state of the economy can be perceived to be strong. Hence, the sign of the change in sentiment coefficient is open.

We gauge sentiment volatility by the conditional variance obtained from $\mathrm{ARCH} / \mathrm{GARCH}$ specifications, as explained in section 4.2. We expect sentiment volatility to have a negative impact on credit growth, and this effect may vary for different sentiment measures. The model also contains a vector of double interaction terms $\left(\hat{\boldsymbol{\sigma}}_{\boldsymbol{S e n t}} \times \boldsymbol{X}\right)$ between the volatility and bank-level variables. These interaction terms will allow us to examine to what extent volatility effects transmit on bank lending through bank-level variables which are shown to affect bank lending behavior in the literature.

\subsection{Effects of excessive volatility on credit growth}

So far, we have hypothesized that credit growth responds proportionately to changes in sentiment volatility. However, periods of turbulence are characterized by high infor- 
mational asymmetry during which adverse selection and moral hazard problems intensify substantially. Thus, when economic agents experience excessive levels of volatility, banks' lending behavior may differ. To consider the possibility of an asymmetric transmission of sentiment volatility to the banks' credit growth, we extend our earlier model by incorporating an interaction term that captures the effects of extreme volatility. In line with the standard approach, to capture asymmetric volatility effects, we create the following dummy variable:

$$
\hat{\sigma}_{\text {Sent }{ }_{j, t}}^{\text {Asy }}= \begin{cases}1 & \text { if } \hat{\sigma}_{\text {Sent }} t_{j, t} \geq 70 \text { Percentile of } \hat{\sigma}_{\text {Sent }_{j}} \\ 0 & \text { Otherwise }\end{cases}
$$

Using this rule for each volatility measure in each G7 country, we set the dummy to 1 when $\hat{\sigma}_{\text {Sent }}$ exceeds its the 70th percentile or zero otherwise. Next, we interact the high volatility dummy, $\hat{\sigma}_{\text {Sent }}^{A s y}$, with bank-level and volatility variables to examine the impact of high volatility on banks' loan growth. The model takes the following form:

$$
\begin{aligned}
& \Delta \ln \left(\text { loans }_{i, t}\right)=\alpha+\gamma_{i} \boldsymbol{X}_{i, t-1}+\boldsymbol{\lambda} \boldsymbol{\Delta} \boldsymbol{S e n t}_{j, t-1}+\boldsymbol{\beta} \hat{\boldsymbol{\sigma}}_{\text {Sent }_{j, t-1}}+\boldsymbol{\theta}\left(\hat{\boldsymbol{\sigma}}_{\text {Sent }_{j, t-1}} \times \hat{\boldsymbol{\sigma}}_{\text {Sent }_{j, t-1}}^{\text {Asy }_{j}}\right) \\
& +\delta\left(\hat{\sigma}_{\text {Sent }_{j, t-1}} \times X_{i, t-1}\right)+\rho\left(\hat{\sigma}_{\text {Sent }_{j, t-1}} \times \hat{\sigma}_{\text {Sent }_{j, t-1}}^{A s y} \times X_{i, t-1}\right) \\
& +\phi \text { MacroControl }_{j, t-1}+\nu_{i}+\text { year }_{t}+\epsilon_{i t}
\end{aligned}
$$

where the double interaction term, $\hat{\boldsymbol{\sigma}}_{\text {Sent }} \times \hat{\boldsymbol{\sigma}}_{\text {Sent }}^{\text {Asy }}$, allows us to examine the impact of excessive volatility effects on credit growth and the triple interaction term, $\hat{\boldsymbol{\sigma}}_{\text {Sent }} \times \hat{\boldsymbol{\sigma}}_{\text {Sent }}^{\boldsymbol{A s y}} \times \boldsymbol{X}_{\boldsymbol{i}}$, captures to what extent excessive volatility effects are transmitted on credit growth through bank specific characteristics.

We implement two approaches to estimate the basic model. First, we use the fixed effect (FE) model with robust standard errors and include year dummies to control for the changes in unobservable annual shocks that may effect bank loans. Second, we use the two-step difference generalized method of moments (GMM) approach and employ a cluster-robust estimator (where clusters are defined by banks) to account for within- 
cluster correlation of the disturbances. Given that the use of these two regression methods have led to similar results and that the magnitude of the lagged dependent variable was small, in what follows we present fixed effects results only. ${ }^{9}$

\section{Data}

Our study spans the period between 1999-2014 and includes commercial, co-operative and savings banks in G7 countries: Canada, Germany, France, the UK, Italy, Japan, and the US. We extract bank-level data from BvD Bankscope. We primarily use unconsolidated statements when available in Bankscope, otherwise, we use consolidated statements (e.g., Lepetit et al., 2015).

To remove the impact of outliers, after constructing the net-loans-to-total-assets (NLTA) ratio, we trim the top and lower 5 percentile of this variable. As a consequence, we identify 9,317 banks for which we have information on all variables, including the Tier 1 capital ratio for the time period and countries covered by our study.

Table 2 provides the basic information on our bank data for each country and for G7. Panel A provides the number of banks, as well as the mean and the standard deviation of NLTA and the gross-loans-to-total-assets ratio (GLTA). It should be noted that while some of the countries contribute as many as 7,109 banks (US), some others contribute as few as 40 banks (Canada (41), France (36) and UK (49)). Although this seemingly large variation in bank numbers across countries may be worrying, the average net-loans-tototal-assets ratios, $\mu_{N L}$, which mostly range between $40 \%$ to $60 \%$, happen to be similar across all countries. ${ }^{10}$ Similarly, the average standard deviation of NLTA ratios, $\sigma_{N L}$, across countries is around $20 \%$. The lowest average standard deviation of NLTA ratio is observed in Japan (13\%) and the highest value is observed in Canada (22\%). We observe

\footnotetext{
${ }^{9}$ We estimated the remaining models using GMM as well. The coefficient estimates from this exercise were similar to those obtained under the fixed effects models, but the Hansen $\mathrm{J}$ test were generally failing. This failure is mainly due to the increases in the explanatory variables that we had to incorporate in the model, which, as a consequence, have lead to a substantial increase in the number of instruments. Hence, we do not report these results.

${ }^{10}$ France stands at the lowest end $(44 \%)$ and Italy stands at the highest end $(66 \%)$.
} 
a similar pattern for the average and standard deviation of GLTA ratios.

Panel B reports the descriptive statistics for the bank-specific variables that we use in our models. The average banks' gross loan growth $\left(\Delta l n_{-} G L\right)$ or net loan growth $\left(\Delta l n_{-} N L\right)$ is about $7.8 \%$ for G7 countries. We also see that the standard deviation of loan growth for both types of loan definitions is around $22 \%$. When we look at the individual country level data, we find that Canada has the highest average loan growth (over 11\%) but its standard deviation is much higher than other countries (over 39\%), while Japan has the lowest loan growth with just over $2.4 \%$. The average Tier 1 ratio is $17.169 \%$, and Canada stands at the highest end (19.5\%) and Japan stands at the lowest end (8.73\%). Furthermore, the average value of impaired loan to gross loan ratio is $1.996 \%$. Canada and US tend to have better quality loans whereas banks in Italy appears to suffer the most on this account. US banks has the lowest average size among the G7 countries. $^{11}$ The average banks' liquidity ratio is $11.86 \%$, and this ratio varies substantially among the G7 countries as it ranges between $8.736 \%$ to $35.561 \%$. Finally, the average profitability is around $0.737 \%$. Banks in Canada has the highest return (1.302\%) while Japanese banks only have an average return on assets about $0.022 \%$. These key ratios seem to suggest that banks in Canada are more resilient than those in other countries against crises. ${ }^{12}$

Panel $\mathrm{C}$ includes the mean and standard deviation for the two macroeconomic variables $(\triangle G D P$ and $I R)$ that we include in our models to control for the demand-side effects on loan growth. The average value for $\triangle G D P$ is $1.894 \%$ and $I R$ is $4.466 \%$, yet these figures deviate across countries.

Panel D reports the mean and standard deviation of the changes $(\triangle C L I)$ and volatility emanating from the leading economic indicators $\left(\hat{\sigma}_{C L I}^{2}\right)$, business sentiment indicators $\left(\triangle B C I, \hat{\sigma}_{B C I}^{2}\right.$, respectively), and consumer sentiment indicators $\left(\triangle C C I, \hat{\sigma}_{C C I}^{2}\right.$, respectively). The average value of $\triangle C L I$ is $0.042, \triangle B C I$ is 0.055 and $\triangle C C I$ is -0.016 , and

\footnotetext{
${ }^{11}$ This should not be too surprising. While there are very large banks in the US, the majority of the banks are small.

${ }^{12}$ During the recent great financial crisis, several high-profile banks in Europe and the US collapsed, some were bailed out, or taken-over. However, to our knowledge, Canada's banking system performed much better and not one Canadian bank failed or openly bailed out.
} 
these values are different for each country. The average value of $\hat{\sigma}_{C L I}^{2}$ is $0.008, \hat{\sigma}_{B C I}^{2}$ is $2.009 \%$ and $\hat{\sigma}_{C C I}^{2}$ is $2.269 \%$, again these values vary substantially across countries. ${ }^{13}$

Table 3 provides the correlation matrix for all the variables. What we observe is that high quality of bank funds (Tier 1) is positively correlated with loan growth whereas the remaining variables, including sentiment volatility measures, which we discuss below, are negatively correlated. Although these correlations provide an impression regarding the impact of each variable on loan growth, given that we are examining data collected from several countries and that each country could be subjected to certain country-specific shocks, a formal empirical investigation should be carried out before acknowledging the effects of these variables on banks' loan growth.

\subsection{Sentiment Indicators}

We extract standardized and amplitude adjusted business confidence indicators, consumer confidence indicators, and composite leading indicators for Canada, Germany, France, the UK, Italy, Japan and the US from the Organisation for Economic Cooperation and Development (OECD) iLibrary. ${ }^{14}$ These indicators provide qualitative information that are useful for monitoring the current economic situation and can be used as an advanced warning for turning points in economic activity and are published under the OECD monthly main economic indicators. ${ }^{15}$

We use the Business Confidence Index (BCI) as a proxy for managers' sentiment, as this indicator combines a set of business tendency survey variables (e.g., the current and immediate future expectations on production, orders and stocks) into a single composite sentiment indicator that summarizes managers' assessment and expectation of the general economic situation. ${ }^{16}$ To capture consumer sentiment we make use of Consumer Confi-

\footnotetext{
${ }^{13} \mathrm{BCI}$ index for Canada is not available, so that the relevant figures in the table are not given.

${ }^{14}$ OECD iLibrary is the online library of the OECD featuring its books, papers and statistics and is the gateway to OECDs analysis and data. However, OECD does not provide business confidence indicator for Canada, see http://www.oecd-ilibrary.org/economics/data/main-economic-indicators_mei-data-en.

${ }^{15}$ Detailed description can be found at https://data.oecd.org/leadind/consumer-confidence-indexcci.htm.

${ }^{16}$ For a detailed methodology how BCIs are computed, the reader is referred to "Business Tendency
} 
dence Index (CCI). Similar to BCI, CCI is based on information collected from consumer opinion surveys regarding the households' intensions for major purchases, their current economic state as compared to the recent past and their expectations for the immediate future (i.e., 3 months). The main characteristic of these surveys is that instead of asking for exact figures, they usually ask for the direction of change by referencing to a "normal" state. For business surveys, they generally use the three-point scale for possible answers (e.g., above normal, normal, or below normal); and use five-point scale (e.g., increase sharply, increase slightly, remain the same, fall slightly, or fall sharply) for consumer surveys. In translating these qualitative results into a time series, only the balance is shown by taking the difference between percentages of respondents giving favourable and unfavourable answers. Both BCI and CCI are expressed as an index (long term average $=100$ ) and they are seasonally adjusted. Because OECD applies the same criteria to construct these indicators across countries, the main advantage of using them is that they are consistent and comparable across all G7 countries.

Last, we use the amplitude adjusted Composite Leading Indicator (CLI) as our third sentiment variable. CLI is an aggregate time series which comprises a set of component series selected from a wide range of key short-term economic indicators. Although the underlying component series can be different for different countries depending on their economic significance, cyclical behavior, data quality, timeliness and availability for the specific country, the CLI is designed to capture turning points and moves in the same directions as the business cycle. ${ }^{17}$

Surveys: A Handbook" at http://www.oecd.org/std/leading-indicators/31837055.pdf.

${ }^{17}$ For example, the component series used to construct the CLI for the US are: the number of dwellings started, net new orders for durable goods, the NYSE composite share prices, consumer sentiment indicator, weekly manufacturing hours of work, purchasing managers index and the spread of interest rates. For the UK, the component series are business climate indicator, new car registrations, consumer confidence indicator, Sterling 3 months interbank lending rate, production: future tendency, finished goods stocks and the FTSE-100 share price index. 


\subsection{Generating a measure of sentiment volatility}

To examine volatility effects of sentiment on bank loan growth, we need to generate a proxy for the uncertainty that arise from agents' perspectives on future economic outcomes of each G7 countries. To that end, we fit an ARCH/GARCH model of the log difference of the business confidence indicators $(\triangle B C I)$, consumer confidence indicators $(\triangle C C I)$, and composite leading indicators $(\triangle C L I)$ over the period between 1980 $2014{ }^{18}$ We should note that prior to estimating the model, we tested and confirmed the presence of ARCH effects using the Lagrange Multiplier (LM) test. The GARCH(p,q) model takes the following form:

$$
\begin{aligned}
\pi_{t} & =\alpha+\Sigma_{k}^{r} \gamma_{k} \pi_{t-k}+\varsigma_{i} i . \text { month }+\epsilon_{t} \\
\hat{\sigma}_{\text {Sent }_{t}} & =\omega_{0}+\Sigma_{k}^{p} \omega_{k} h_{t-k}+\Sigma_{k}^{q} \omega_{k} \epsilon_{t-k}^{2}
\end{aligned}
$$

where $\pi_{t}$ denotes $\Delta B C I, \Delta C C I$, or $\Delta C L I$, i.month captures month effects, $\epsilon_{t}=\mu_{t} \sqrt{\hat{\sigma}_{\text {Sent }}}$ where $\mu_{t}$ is a zero mean, unit variance white noise process.

We estimate a variant of the above model by fitting an $\mathrm{ARCH}(\mathrm{p})$ or $\operatorname{GARCH}(\mathrm{p}, \mathrm{q})$ model for each country and sentiment measure. For all countries, we used a low order $\operatorname{GARCH}(\mathrm{p}, \mathrm{q})$ model with the exception of Japan's leading indicator volatility where a simple $\mathrm{ARCH}(2)$ model was preferred. ${ }^{19}$ In all cases, we examine the standardized residuals. Ascertaining that the selected model is well specified, we take the within year average of the estimated conditional variances to match the frequency of the bank-level data. This series is then used as a measure of volatility for the future economic outcomes perceived by each agent, which we denote as $\hat{\sigma}_{\text {Sent }}$ in equations 2 and $3 .^{20}$ Here, higher levels of conditional variance imply higher uncertainty of the future economic outcomes

\footnotetext{
${ }^{18} \mathrm{ARCH}$ models are estimated for a longer period for each country than the span of the data that we extracted from the Bankscope database, to work with a longer set of data to compute the parameters. Standard references are Engle (1982) and Bollerslev (1986).

${ }^{19}$ To save space, we do not report the details from these models, but they are available upon request.

${ }^{20}$ Several researchers have implemented a similar approach to examine the uncertainty effects on real economic activities.
} 
perceived by the economic agents. Hence, it is important and relevant to examine the banks' lending behavior as volatility perceived by the economic agents varies over time. Table 2 Panel D provides the average and standard deviation of sentiment volatility for each country, $\hat{\sigma}_{\text {Sent }}$, that we observe in the data.

\section{$5 \quad$ Empirical Findings}

This section presents our findings on bank loans growth with respect to the bank characteristics, the level and volatility of sentiment and macroeconomic control variables. All models allow for country-specific and year fixed effects and all tables report robust standard errors.

\subsection{Basic bank lending model results}

Table 4 reports the results for our basic model for both net-loan growth (the former 2 columns) and gross-loan growth (the latter 2 columns). This model is estimated using both fixed effects and the two-step difference GMM approach. In order to determine the appropriateness of the GMM results, we report the heteroscedasticity-consistent Hansen $J$-test for the validity of the instrument set, and the Arellano-Bond test for the absence of second-order residual autocorrelation (AR2 test). Both tests show that the models are well-specified and there is no second-order serial correlation. Note that the coefficient estimates from both approaches, especially those associated with the bank-level variables, are very similar and that even though the lagged dependent variable is significant its magnitude is less than $10 \%$.

When we peruse the table, we immediately see that all coefficient estimates take the expected signs. First of all, we observe that high quality bank funding, Tier 1 , has a positive and highly significant impact on the growth of bank loans. This implies that wellcapitalized banks are in a better position, with respect to less-capitalized banks, to absorb shocks and actual credit and liquidity risk exposures, so that they can continue with 
their lending activities. Such banks, which hold more capital in excess of the minimum requirement to meet prudential regulation standards, adjust their lending less especially during the economic downturns in order to avoid regulatory capital shortfalls. ${ }^{21}$ Secondly, we see that the impaired loans have a negative impact on loan growth. This suggest that banks which write-off significant amounts of bad-credit from their books reduce their loan growth. These findings are consistent with Laeven and Majnoni (2003); Delis et al. (2014) who also found a significant negative relationship between loan growth and loan losses.

Furthermore, we observe that loan growth is negatively related with bank size. For instance, Uchida et al. (2008) suggested that small banks have a comparative advantage in processing soft information and delivering relationship lending, which helps explain the negative coefficient. With respect to the return-on-assets, we only find negative and highly significant coefficients from the fixed effect model, while GMM approach suggests that return-on-assets does not affect loan growth. One possible interpretation for a negative coefficient on size and return-on-assets may be that banks which experience lower returns and which are small in size act more aggressively in extending their customer base by seizing new lending opportunities. Moreover, according to a standard Cournot model with capacity constraints, smaller banks may have to offer a lower rate than banks with higher capacity to attract customers (Sapienza, 2004). Another possible explanation suggest that larger banks have better access to markets and experience economies of scale in managing wholesale deposits (e.g., large-denomination certificates of deposit and subordinated debt), could have less interest in attracting the marginal retail depositors, and thus offer lower deposit rates than other banks (Tennant and Sutherland, 2014). In addition, confirming our expectations, we find that there is a positive relationship between liquidity and loan growth. ${ }^{22}$

Last, we find that the macroeconomic variables that capture the demand-side effects

\footnotetext{
${ }^{21}$ See Kosak et al. (2015) for a more detailed discussion on high quality capital.

${ }^{22}$ Research has shown that banks continue their lending activities if they had better access to deposit financing. For example see Ivashina and Scharfstein (2010).
} 
have the correct signs but they are insignificant in general. This may be due to the fact that our models contain year fixed effects which may be fully absorbing the demand effects.

\subsection{The effects of sentiment on bank lending behavior}

In this section, we report our findings on the effects of sentiment on banks' credit growth. Table 5 lists all the bank variables whose effects we examined in the previous tables as well as the level, volatility and extreme volatility effects of sentiment for each categories, in the order of composite leading indicator (CLI), business sentiment (BCI) and consumer sentiment (CCI) on banks' loan growth. ${ }^{23}$ The first column under each sentiment category presents the level and volatility effects, while the next one introduces the extreme volatility effect. All models include country and year fixed effects.

Inspecting Table 5, we can see that the impact of bank-level variables is the same as that in Table 4. Therefore, we focus on the level and volatility effects of sentiment on banks' lending behavior. First, we find that for all three categories, change in sentiment has a significantly negative impact on banks' loan growth, except for the model in column 5. In general, positive changes in sentiment measures are typically associated with the heating up of the economy which eventually renders the central bank to take action by increasing the interest rate to stop the buildup of inflationary pressures. Hence, a negative coefficient on sentiment may be explained by the bank mangers' expectations on future interest rate increases. Our findings are consistent with Delis et al. (2014), who also reported that changes in sentiment affect loan growth negatively.

Regarding the volatility effects of sentiment, we find that it always has a negative and significant impact on loan growth regardless of its source. Negative effect of volatility on bank loan growth is sensible as during periods of volatility, bank managers would behave more conservatively in issuing new loans. In particular, given that sentiment volatility is

\footnotetext{
${ }^{23}$ We suppress the estimated coefficients associated with macroeconomic variables that capture the demand-side effects and the constant to conserve space. These estimates are available from the authors.
} 
driven by expectations about the future economic outcomes, the information embedded in these volatility series would suggest that firm managers cannot accurately predict returns from outstanding projects (e.g., Baum et al., 2009). In such an environment, it would be naïve from bank managers' point of view to expand credit growth for such behavior could lead to more write-offs as businesses are more prone to bankruptcies during periods of volatility. In extreme cases of volatility, we observe a very significant and negative effect, which further strengthen our view that under higher uncertainty banks' loan growth decline faster. The only counter view to this argument is for the case of excessive consumer sentiment volatility: although banks reduce their overall lending in periods of extreme consumer volatility, this effect is slightly dampened in comparison to the other two cases we examined.

When we examine the impact size of volatility effects on bank loans we find that it (as high as 13\%) is much stronger than that of the changes in sentiment (less than 1\%). Furthermore, we find that the volatility effects emanating from business sentiment has the least impact (around 2\%) and that emanating from the consumer sentiment is the highest at around (13\%). One possible explantation as to why consumer sentiment volatility affects bank credit growth more than business sentiment volatility could be the fact that large variations on consumers' expectations on future economic outcomes often results in reduced or postponed investments and purchases on goods and services suggesting a curtailment of bank loans (e.g. Kilian, 2008).

Our observations may be useful when we consider the research that have examined the uncertainty effects on bank lending behavior, as it is widely acknowledged that banks tend to curtail their loan supply after monetary and financial shocks, making it difficult for bank-dependent borrowers to rely on external finance. ${ }^{24}$ As the banks' risk preferences changes while uncertainty varies over time, bank managers may be more willing to extend loans during periods of tranquility and less so when uncertainty reaches extreme levels. In addition, because monitoring costs also change with the the changes in economic

\footnotetext{
${ }^{24}$ See for instance, Berger and Udell (2002); Ivashina and Scharfstein (2010) and Ferri et al. (2014).
} 
environment, this may further affect availability of bank credit.

\subsection{Does uncertainty effects transmit through Bank-specific char- acteristics?}

In this section, we scrutinize the evolution of bank credit by examining whether the adverse effects of sentiment volatility is transmitted on bank loan growth through bankspecific characteristics. Table 6 reports our main results. ${ }^{25}$ Once again, all models contain year and firm specific effects. The first three rows provide the effect of sentiment $(\Delta S e n t)$, sentiment volatility $\left(\hat{\sigma}_{\text {Sent }}^{2}\right)$, and the extreme cases $\left(\hat{\sigma}_{\text {Sent } \times \text { Dum }}^{2}\right)$ to provide a basis for the analysis. The effects of change in sentiment, its volatility and extreme sentiment are similar to that reported in Table 5. The only difference emerges with the effect of business confidence volatility, which is insignificant, possibly due to the additional interaction terms that we introduced into the model.

We next look at the impact of bank-specific variables on bank loan growth as sentiment volatility changes. The effect of Tier-1 on bank loan growth does not change with the introduction of sentiment volatility; i.e. the interaction terms associated with this variable are not significant. However, Tier-1 It has a positive effect on loan growth regardless of the level of volatility. Similarly, the effect of bank liquidity is always positive and significant, and this relation does not change with the extent of sentiment volatility, as the associated interaction terms are not significant. Hence, we conclude that the impact of sentiment volatility on bank loan growth does not transmit through these two variables.

Impaired loans continue to play a negative role on banks' loan growth. The double interaction terms with sentiment volatility is negative and significant in four out of six cases. The extreme volatility effect, captured by the triple interaction, is positive and significant only for the case of consumer sentiment. Turning to the role of size, we find that it has a negative impact on loan growth, echoing our earlier findings. However, the

\footnotetext{
${ }^{25}$ We suppress the coefficients associated with macroeconomic variables that capture the demand-side effects and the constant to save space, these results are available upon request.
} 
interaction terms associated with size assume positive or negative signs. But examining the extreme volatility effects, we find that uncertainty reduces credit growth regardless of the size of the bank.

Lastly, we turn to the effect of return-of-assets on bank loan growth. We find that the own effect of asset returns has a significant negative effect, as we observed in our earlier tables. However, when we look at the sign associated with the double interactions, we find that these coefficients are consistently significant and positive, yet, the triple interaction coefficients are negative and significant. These coefficient estimates indicate that although banks with lower return to assets are more aggressive in periods of tranquility, when the environment is volatile banks with lower returns on assets reduce their credit growth more sharply than those banks with higher returns. Hence, our results show that uncertainty effects dissipate for those banks with higher return on assets.

\subsubsection{Full impact of sentiment volatility}

So far, we examined the coefficient estimates related to volatility interactions and discussed to what extent sentiment volatility effects transmit through bank-level variables onto credit growth. However, this discussion does not show the full impact of volatility effects as bank variables maybe at different levels at any point in time. That is, unless we take into account the joint effect of the interaction terms with uncertainty while considering the state of the bank level variables (i.e the extent of impaired loans, size and return-on-assets), it is not easy to visualize the full effect of uncertainty on credit growth. To gauge the full impact of uncertainty, we must evaluate the total derivative of credit growth with respect to sentiment volatility. For demonstration purposes, we present the total derivative of equation (3) with respect to $\hat{\sigma}_{\text {Sent }}^{2}$, where all bank specific variables are evaluated at their means except for return on asset.

$$
\begin{aligned}
\partial y_{t} / \partial \hat{\sigma}_{\text {Sent }_{k}}^{2} & =\beta_{k}+\theta_{k} \hat{\sigma}_{\text {Sent }_{k}}^{\text {Asy }}+\delta_{k_{i}} \bar{X}_{\text {Impaired }}+\delta_{k_{i}} \bar{X}_{\text {Size }}+\delta_{k_{i}} X_{R O A A}^{*} \\
& +\rho_{k_{i}}\left(\hat{\sigma}_{\text {Sent }_{k}}^{\text {Asy }} \times \bar{X}_{\text {Impaired }}\right)+\rho_{k_{i}}\left(\hat{\sigma}_{\text {Sent }_{k}}^{\text {Asy }} \times \bar{X}_{\text {Size }}\right)+\rho_{k_{i}}\left(\hat{\sigma}_{\text {Sent }_{k}}^{\text {Asy }} \times X_{R O A A}^{*}\right)
\end{aligned}
$$


In this equation, $k$ depicts business, consumer or leading indicator volatility. $X_{R O A A}^{*}$ refers to return-on-assets including the $10 t h, 25 t h, 50 t h, 75 t h$, and $90 t h$ percentiles. The other two bank-specific variables, $\bar{X}_{\text {Impaired }}$ and $\bar{X}_{\text {Size }}$, are set to their averages. We compute the above full effect for volatility and excessive volatility for each $k$ rendering us two sets of results as we allow one bank variable vary at a time. The computed values and the associated $95 \%$ confidence intervals are then plotted in Figures 2 and 3. In computing the above equation, the parameter estimates for $\beta, \theta, \delta_{i}, \rho_{i}$ are set to their point estimates given in Table 6. Although the results we present in here are obtained under certain assumptions, that as $R O A A$ varies the other two bank-specific variables are set to their observed mean, and that these values are obtained for the full sample rather than per country, Figures 2-3 can help us visualize the full impact of uncertainty as a specific bank characteristic changes at a time. This exercise is carried out and plotted for impaired loans and size variables, as well.

Let's focus on the first column of Figure 2 which plots the full effect of leading indicator uncertainty on credit growth as one bank-level variable varies while the other two are fixed to its mean. These figures show that under leading indicator uncertainty although changes in impaired loans does not make a significant difference with respect to credit growth, banks tend to increase their credit growth as size and returns on assets improve. ${ }^{26}$ Turning to Figure 3 and inspecting the results presented in the first column, we find a clear negative effect regarding the role of uncertainty on credit growth as uncertainty reaches extreme levels. In this case, it is only for the banks with higher returns that the adverse effects of uncertainty is lower. Overall, these two sets of figures show that although low levels of leading indicator volatility may not deter credit growth, as volatility increases, banks reduce their loan growth substantially.

The second column of Figures 2 and 3 plot the full effect of business volatility. An inspection of the two sets show that these figures are very similar except that the fall in

\footnotetext{
${ }^{26}$ In all three cases the computed full impact is not significantly different from zero. However, one should bear in mind that these values are obtained under certain assumptions and it is useful to focus on the trend rather than the impact size or significance at this point.
} 
level when uncertainty reaches extreme levels. Looking at the trend movements we see that an increase in bank size and bank returns lead to higher credit under uncertainty. As expected an increase in the size of impaired loans render lower credit growth. The size impact of business uncertainty as bank level variables change is positive yet insignificant when uncertainty reaches extreme levels and positive and significant under less volatile periods. The insignificance of uncertainty effects may be explained by the fact that banks have close relationship with the firms that they lend to, and that banks monitor the performance of business to make sure that loans are repaid as contracted in the first place. Hence, the fact that firms foresee volatility in the outlook may not affect banks' views about firms' ability to payback their loans. In fact, referring to options theory, rising business sentiment uncertainty may encourage banks to wait for new information before calling funds back to avoid losing established linkages with businesses (Dixit and Pindyck, 1994; Kulatilaka and Perotti, 1998) and extend further loans to help businesses achieve higher profits as they go into new ventures. In this context, business sentiment volatility and leading indicator volatility differs considerably, as leading indicator volatility measures the health of the overall economic environment, whereas business volatility refers to how businesses perceive the future from businesses perspective given the options available to them.

Last, we look at the effect of uncertainty on credit growth as consumer sentiment volatility changes. The results in both sets of figures show that consumer volatility leads to a significant fall in credit growth. Recalling that aggregate consumption is about $70 \%$ of GDP, this observation should be not be surprising. When consumers perceive volatility in the outlook, they tend to reduce their expenditures on goods and services to smooth their consumption over the horizon. This prudent behavior further affects businesses as they cut back their fixed investment projects in response to a drop in consumer expenditures. ${ }^{27}$ Hence, bank loans decline in periods of consumer unrest.

Our results provide evidence that the source of the level and volatility of sentiment

\footnotetext{
${ }^{27}$ See Bloom (2009) who argues that volatility bursts cause a rapid drop and rebound in aggregate output and employment, as firms temporarily paused their investment and hiring activities.
} 
have differing effects on banks' loan growth through. Especially, our findings show that sentiment volatility effects differ due to differing transmission on bank loans through various bank-specific variables. Given our findings, future studies should consider transmission of volatility effects through bank characteristics, as their omission would lead to biases regarding banks' lending behavior.

\subsection{Robustness check and additional evidence}

Table 7 provides our new set of results when we replace gross loan growth with net loan growth as the dependent variable. The table presents the results for the widest model with double interactions and triple interactions. The first two columns present the results for the changes and volatility that arise from the leading indicator, columns 3-4 and the last two columns present results for the business and consumer sentiment, respectively. These results are very similar to our earlier findings providing support to our claim that the level and sentiment volatility affects bank loans and that this effect varies with respect to its source.

To further check the robustness of our results, we re-estimated our models using commercial banks only and obtained similar observations. Lastly, the inclusion of stock price volatility into the model did not alter our main conclusions. To save space, we do not report these results but they are available upon request.

\section{Conclusion}

Different from the literature, this study investigates to what extent economic agents' sentiment affects banks' lending behavior. In our analysis, we particularly examine the sentiment effects that emanate from the changes and volatility of three different sources, leading indicator, business and consumer sentiments, on banks' lending behavior. To carry out the analysis, we construct a bank-level panel data set that is comprised of thousands of banks extracted from the Bankscope database for the G7 countries including 
Canada, Germany, France, the UK, Italy, Japan, and the US. The data cover the period between 1999-2014.

In this study, we first show that the changes in sentiment as well as its volatility effects banks loan growth negatively. We next examine whether this effect changes as banks experience volatility at excessive levels. We generally find that at excessive levels of sentiment volatility, banks further reduce their loan growth.

While carrying our analysis we scrutinize and discuss the impact of several bankspecific characteristics, including capital strength, impaired loans, size, liquidity and return-on-assets. Additionally, we examine whether the effects of sentiment volatility transmits its impact on bank loans through these bank-specific variables. We find that volatility transmits its effects on bank loan growth through impaired loans, size and return-on-assets. We provide evidence that banks further reduce their loans if the bank carry higher impaired loans under higher volatility. We also find that the negative impact of uncertainty is lower if banks experience higher return on their assets. Furthermore, we show that uncertainty transmits its impact on bank loans through size while uncertainty effects are generally dampened as bank size increases.

Interestingly, even though both high quality bank funding strategy (i.e., Tier-1 bank capital) and liquidity play a vital role in credit growth, sentiment uncertainty does not transmit its impact through them. Last, but not the least, our examination show that the degree of impact of changes in the sentiment and its volatility is dependent on the source. Given that these interaction effects are significant, their omission would lead to biases in examining the effects of sentiment on banks' lending behavior. Future research should carefully consider similar interaction effects.

\section{References}

Altunbas, Y., Gambacorta, L., and Marques-Ibanez, D. (2010). Bank risk and monetary policy. Journal of Financial Stability, 6(3):121-129. 
Bachmann, R. and Sims, E. R. (2012). Confidence and the transmission of government spending shocks. Journal of Monetary Economics, 59(3):235-249.

Barsky, R. B. and Sims, E. R. (2012). Information, animal spirits, and the meaning of innovations in consumer confidence. The American Economic Review, 102(4):13431377.

Baum, C. F., Caglayan, M., and Ozkan, N. (2009). The second moments matter: The impact of macroeconomic uncertainty on the allocation of loanable funds. Economics Letters, 102(2):87-89.

Berger, A. N. and Udell, G. F. (2002). Small business credit availability and relationship lending: The importance of bank organisational structure. The Economic Journal, 112(477):F32-F53.

Bertay, A. C., Demirguc-Kunt, A., and Huizinga, H. (2015). Bank ownership and credit over the business cycle: Is lending by state banks less procyclical? Journal of Banking E Finance, 50:326-339.

Bloom, N. (2009). The Impact of Uncertainty Shocks. Econometrica, 77(3):623-685.

Bollerslev, T. (1986). Generalized autoregressive conditional heteroskedasticity. Journal of econometrics, 31(3):307-327.

Brei, M., Gambacorta, L., and von Peter, G. (2013). Rescue packages and bank lending. Journal of Banking Ef Finance, 37(2):490-505.

Brei, M. and Schclarek, A. (2013). Public bank lending in times of crisis. Journal of Financial Stability, 9(4):820 - 830.

Brewer, E., Deshmukh, S., and Opiela, T. P. (2014). Interest-rate uncertainty, derivatives usage, and loan growth in bank holding companies. Journal of Financial Stability, $15: 230-240$. 
Calmès, C. and Théoret, R. (2014). Bank systemic risk and macroeconomic shocks: Canadian and US evidence. Journal of Banking \& Finance, 40:388-402.

Cull, R. and Martínez Pería, M. S. (2013). Bank ownership and lending patterns during the 2008-2009 financial crisis: Evidence from Latin America and Eastern Europe. Journal of Banking \& Finance, 37(12):4861-4878.

De Haas, R. and Van Lelyveld, I. (2010). Internal capital markets and lending by multinational bank subsidiaries. Journal of Financial Intermediation, 19(1):1-25.

Delis, M. D., Kouretas, G. P., and Tsoumas, C. (2014). Anxious periods and bank lending. Journal of Banking \& Finance, 38:1-13.

Dixit, R. K. and Pindyck, R. S. (1994). Investment under uncertainty. Princeton university press.

Engle, R. F. (1982). Autoregressive conditional heteroscedasticity with estimates of the variance of United Kingdom inflation. Econometrica: Journal of the Econometric Society, 50(4):987-1007.

Ferri, G., Kalmi, P., and Kerola, E. (2014). Does bank ownership affect lending behavior? evidence from the euro area. Journal of Banking \& Finance, 48:194-209.

Gambacorta, L. and Marques-Ibanez, D. (2011). The bank lending channel: lessons from the crisis. Economic Policy, 26(66):135-182.

Iannotta, G., Nocera, G., and Sironi, A. (2007). Ownership structure, risk and performance in the european banking industry. Journal of Banking \& Finance, 31(7):21272149.

Ivashina, V. and Scharfstein, D. (2010). Bank lending during the financial crisis of 2008. Journal of Financial Economics, 97(3):319-338. 
Kashyap, A. K. and Stein, J. C. (2000). What do a million observations on banks say about the transmission of monetary policy? American Economic Review, pages 407428.

Kilian, L. (2008). The economic effects of energy price shocks. Journal of Economic Literature, 46(4):871-909.

Kosak, M., Li, S., Loncarski, I., and Marinc, M. (2015). Quality of bank capital and bank lending behavior during the global financial crisis. International Review of Financial Analysis, 37(0):168-183.

Kulatilaka, N. and Perotti, E. C. (1998). Strategic growth options. Management Science, 44(8):1021-1031.

Laeven, L. and Majnoni, G. (2003). Loan loss provisioning and economic slowdowns: too much, too late? Journal of financial intermediation, 12(2):178-197.

Lepetit, L., Saghi-Zedek, N., and Tarazi, A. (2015). Excess control rights, bank capital structure adjustments, and lending. Journal of Financial Economics, 115(3):574-591.

Puri, M., Rocholl, J., and Steffen, S. (2011). Global retail lending in the aftermath of the us financial crisis: Distinguishing between supply and demand effects. Journal of Financial Economics, 100(3):556-578.

Quagliariello, M. (2009). Macroeconomic uncertainty and banks lending decisions: the case of Italy. Applied Economics, 41(3):323-336.

Sapienza, P. (2004). The effects of government ownership on bank lending. Journal of financial economics, 72(2):357-384.

Tennant, D. and Sutherland, R. (2014). What types of banks profit most from fees charged? a cross-country examination of bank-specific and country-level determinants. Journal of Banking \& Finance, 49:178-190. 
Uchida, H., Udell, G. F., and Watanabe, W. (2008). Bank size and lending relationships in japan. Journal of the Japanese and International Economies, 22(2):242-267. 


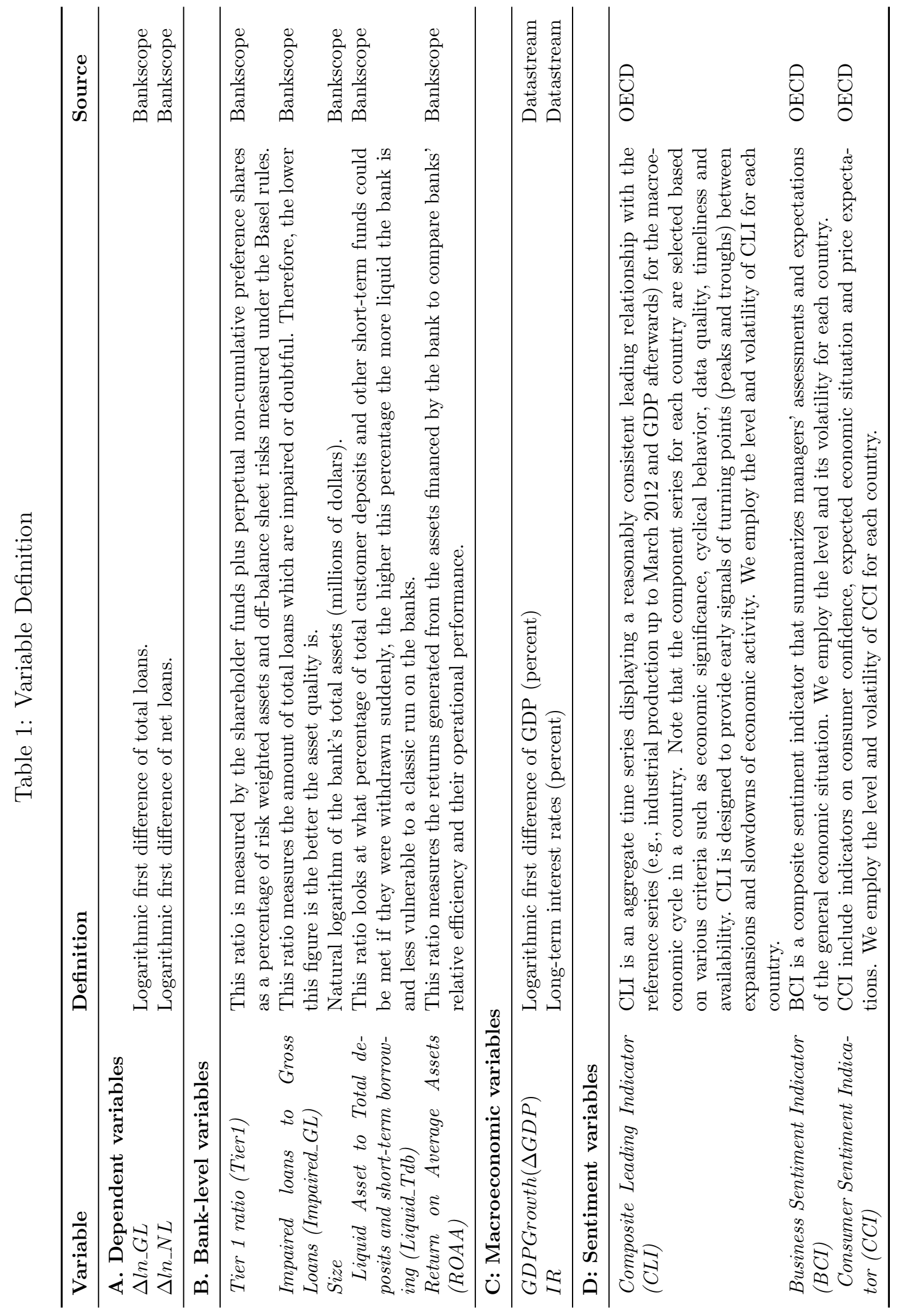




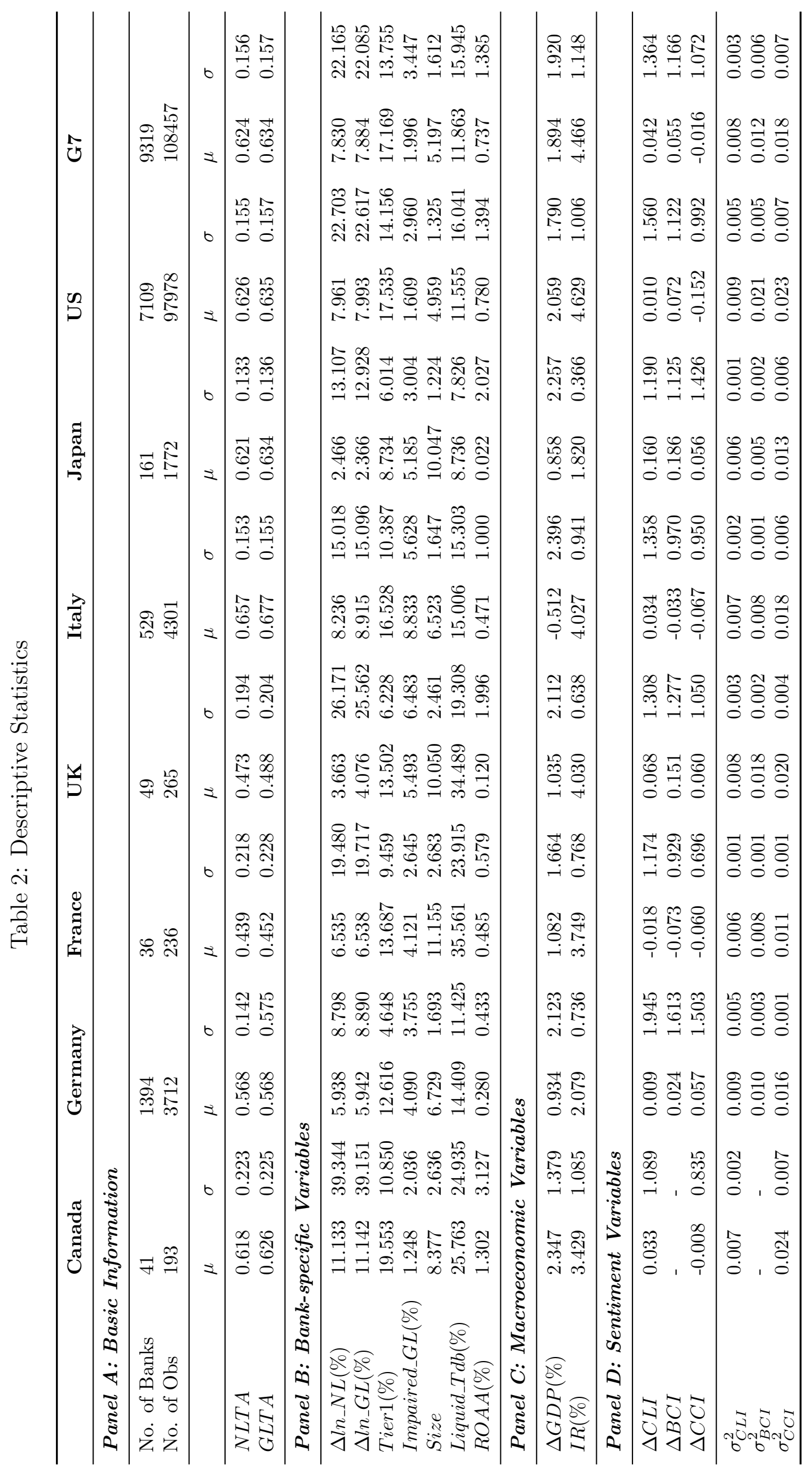




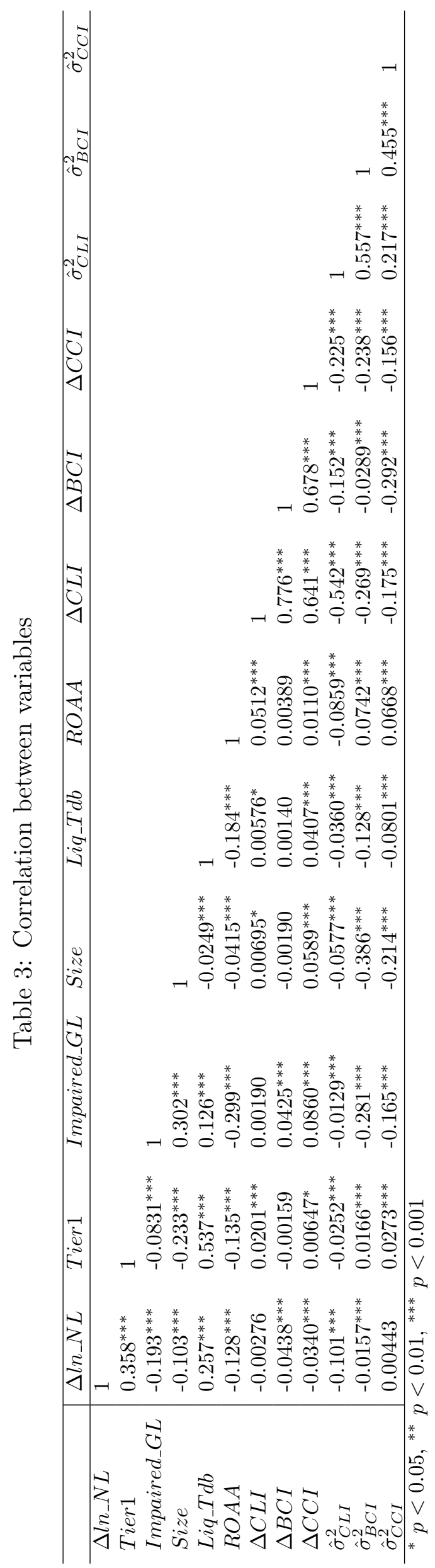


Table 4: Results from the Basic Bank Lending Model

\begin{tabular}{|c|c|c|c|c|}
\hline & \multicolumn{2}{|c|}{$\left(\Delta l n_{-} N L\right)$} & \multicolumn{2}{|c|}{$\left(\Delta l n_{-} G L\right)$} \\
\hline & $F E$ & $G M M$ & $F E$ & $G M M$ \\
\hline$\Delta \ln _{-} N L_{t-1}$ & & $\begin{array}{c}0.0813^{* * *} \\
(0.015)\end{array}$ & & \\
\hline$\Delta l n_{-} G L_{t-1}$ & & & & $\begin{array}{c}0.0848^{* * *} \\
(0.014)\end{array}$ \\
\hline $\operatorname{Tier} 1_{t-1}$ & $\begin{array}{c}0.00603^{* * *} \\
(0.001)\end{array}$ & $\begin{array}{c}0.00527^{* * *} \\
(0.002)\end{array}$ & $\begin{array}{c}0.00601^{* * *} \\
\quad(0.001)\end{array}$ & $\begin{array}{c}0.00455^{* * *} \\
(0.002)\end{array}$ \\
\hline Impaired_G $L_{t-1}$ & $\begin{array}{c}-0.0169^{* * *} \\
(0.001)\end{array}$ & $\begin{array}{c}-0.00752^{*} \\
(0.004)\end{array}$ & $\begin{array}{c}-0.0171^{* * *} \\
(0.001)\end{array}$ & $\begin{array}{c}-0.00777^{*} \\
(0.004)\end{array}$ \\
\hline$S i z e_{t-1}$ & $\begin{array}{c}-0.188^{* * *} \\
(0.008)\end{array}$ & $\begin{array}{c}-0.289^{* * *} \\
(0.041)\end{array}$ & $\begin{array}{c}-0.186^{* * *} \\
(0.008)\end{array}$ & $\begin{array}{c}-0.283^{* * *} \\
(0.041)\end{array}$ \\
\hline$L i q_{-} T d b_{t-1}$ & $\begin{array}{c}0.00236^{* * *} \\
(0.000)\end{array}$ & $\begin{array}{c}0.00237^{* *} \\
(0.001)\end{array}$ & $\begin{array}{c}0.00237^{* * *} \\
\quad(0.000)\end{array}$ & $\begin{array}{c}0.00269^{* *} \\
(0.001)\end{array}$ \\
\hline$R O A A_{t-1}$ & $\begin{array}{c}-0.0115^{* * *} \\
(0.002)\end{array}$ & $\begin{array}{c}0.00854 \\
(0.007)\end{array}$ & $\begin{array}{c}-0.0114^{* * *} \\
(0.002)\end{array}$ & $\begin{array}{c}0.00806 \\
(0.007)\end{array}$ \\
\hline$\triangle G D P$ & $\begin{array}{c}0.00125 \\
(0.001)\end{array}$ & $\begin{array}{c}-0.0156^{*} \\
(0.009)\end{array}$ & $\begin{array}{c}-0.000392 \\
(0.001)\end{array}$ & $\begin{array}{r}-0.0120 \\
(0.009)\end{array}$ \\
\hline$I R$ & $\begin{array}{c}-0.00179 \\
(0.002)\end{array}$ & $\begin{array}{c}-0.0420 \\
(0.028)\end{array}$ & $\begin{array}{c}0.00107 \\
(0.002)\end{array}$ & $\begin{array}{c}-0.0403 \\
(0.027)\end{array}$ \\
\hline Cons & $\begin{array}{c}0.912^{* * *} \\
(0.047)\end{array}$ & & $\begin{array}{c}0.894^{* * *} \\
(0.046)\end{array}$ & \\
\hline$N$ & 97196 & 80806 & 97196 & 80806 \\
\hline$R^{2}$ & 0.422 & & 0.423 & \\
\hline AR2 test (p_value) & & 0.590 & & 0.587 \\
\hline Hansen J test (p_value) & & 0.138 & & 0.082 \\
\hline
\end{tabular}

Standard errors in parentheses

${ }^{*} p<0.10,{ }^{* *} p<0.05,{ }^{* * *} p<0.01$ 


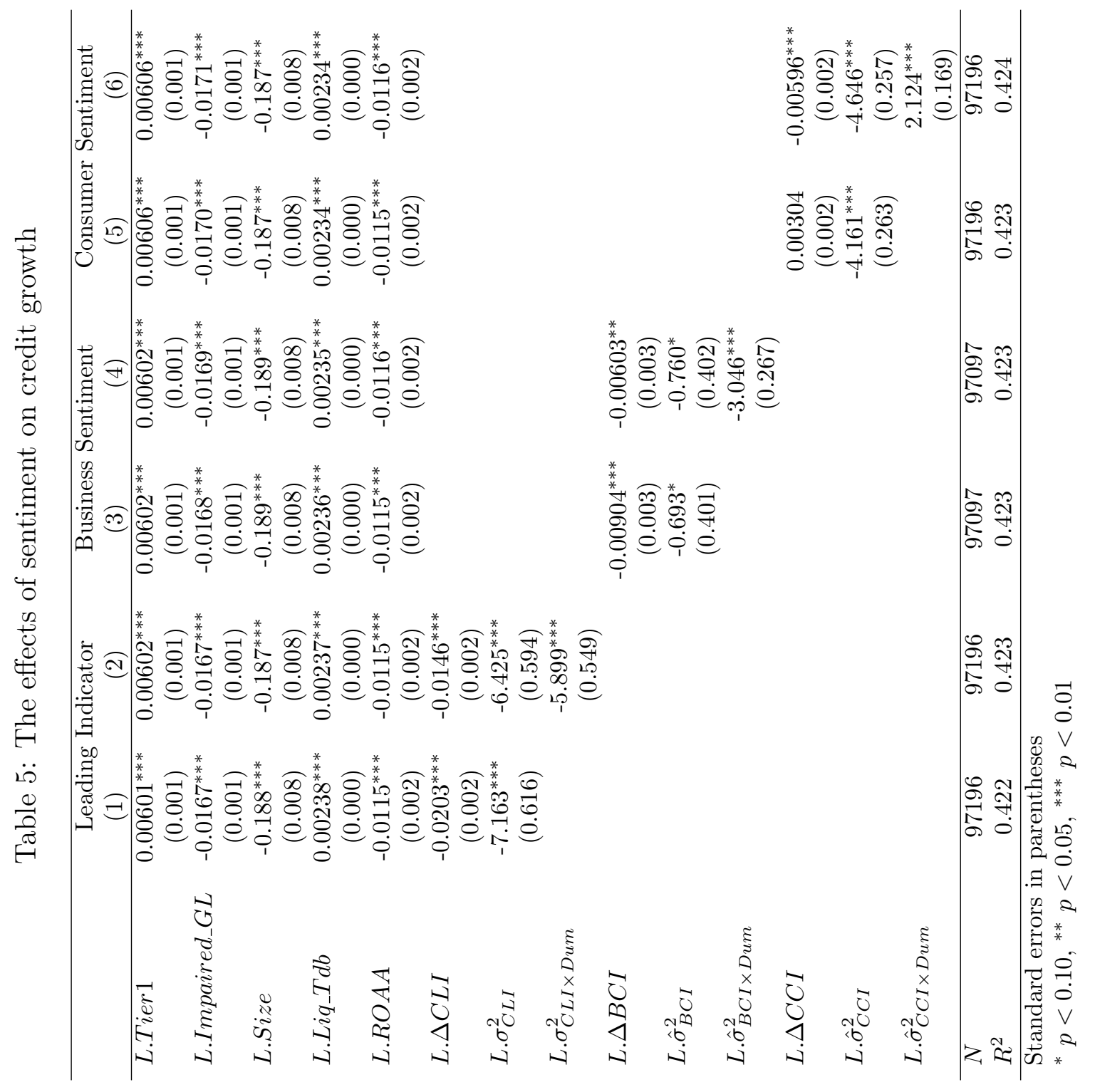




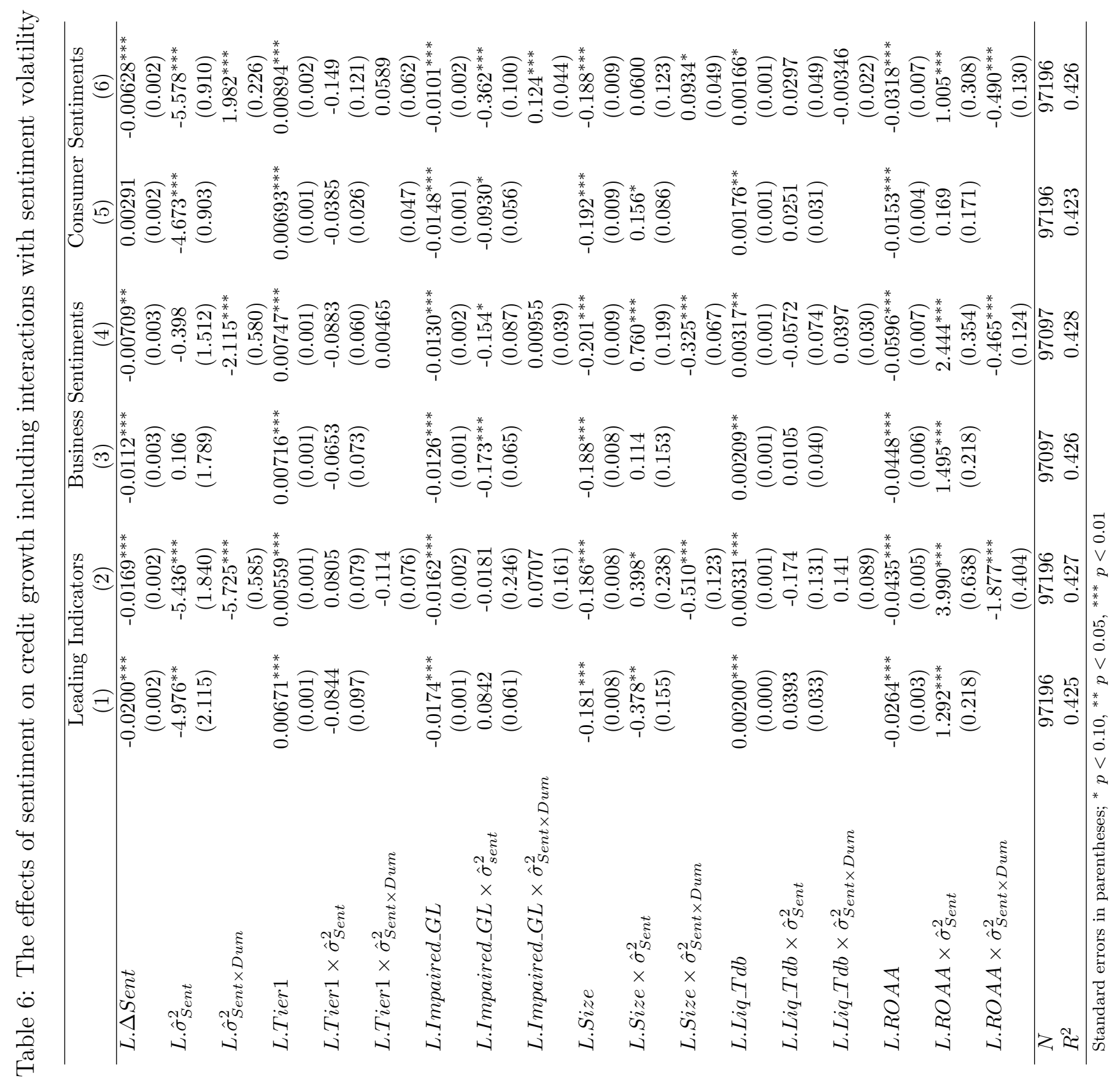




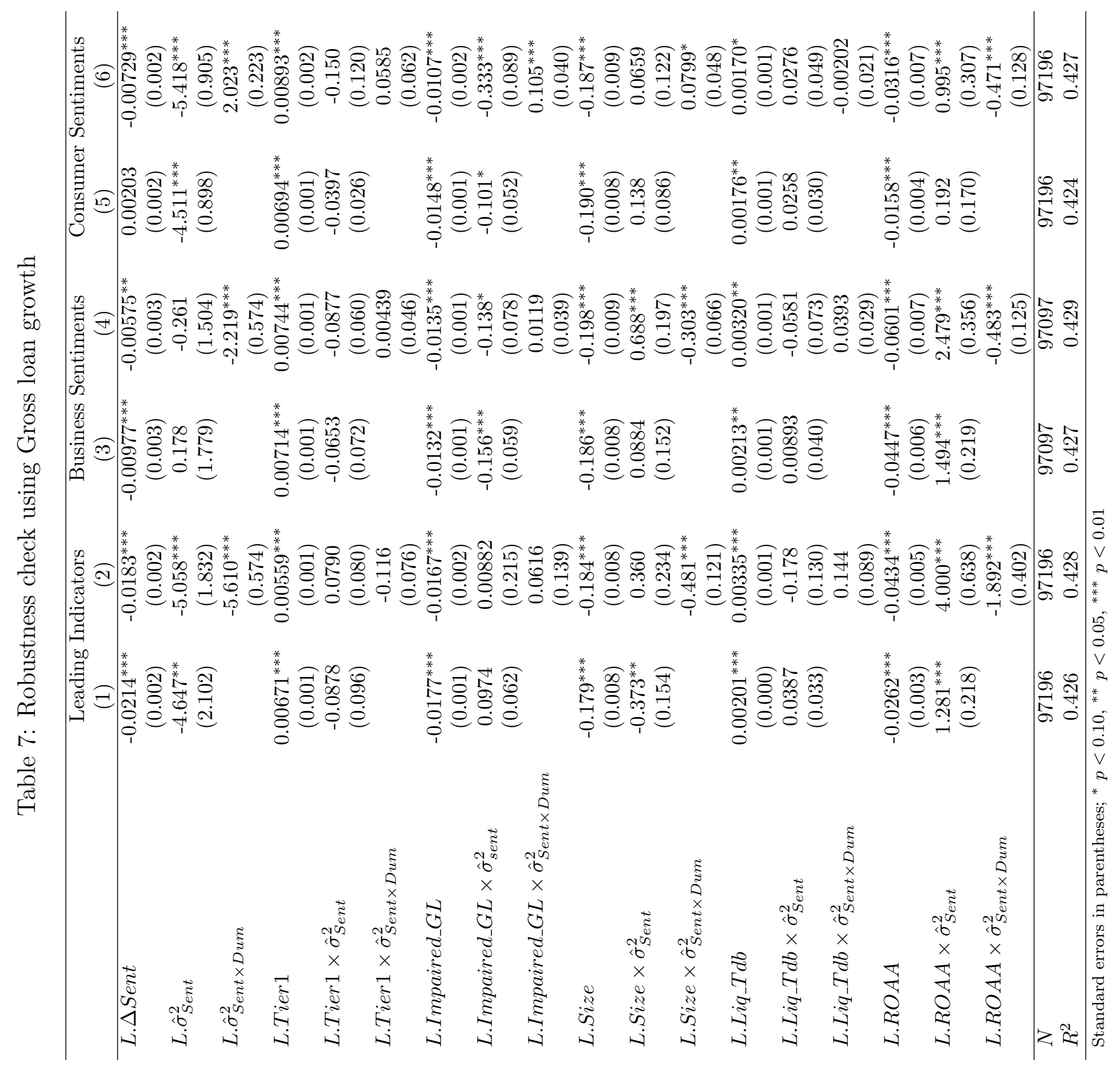




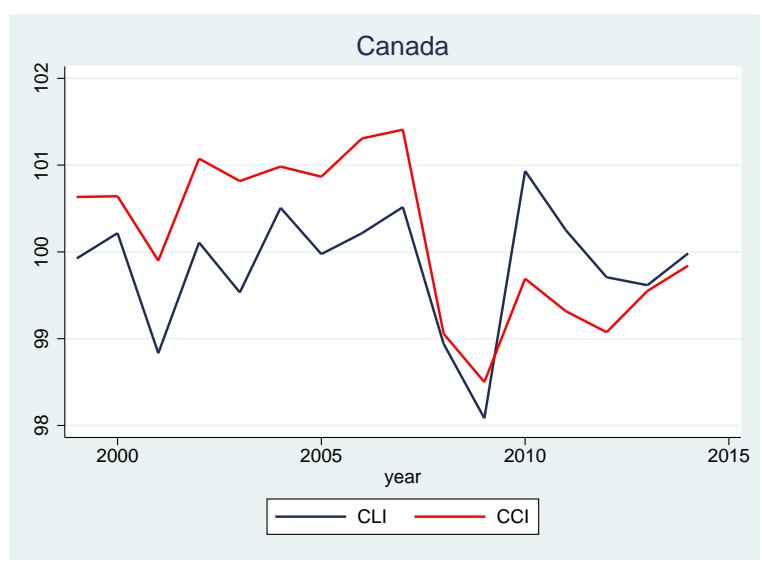

(a) Canada Sentiment Indicators

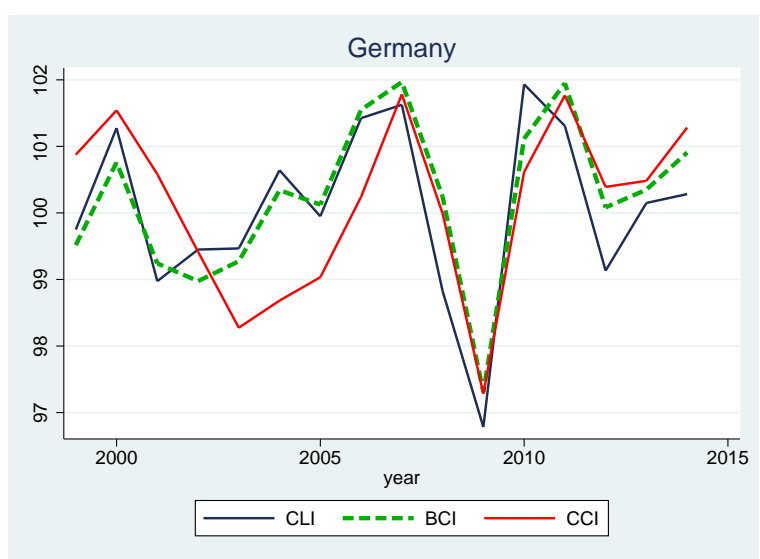

(c) Germany Sentiment Indicators

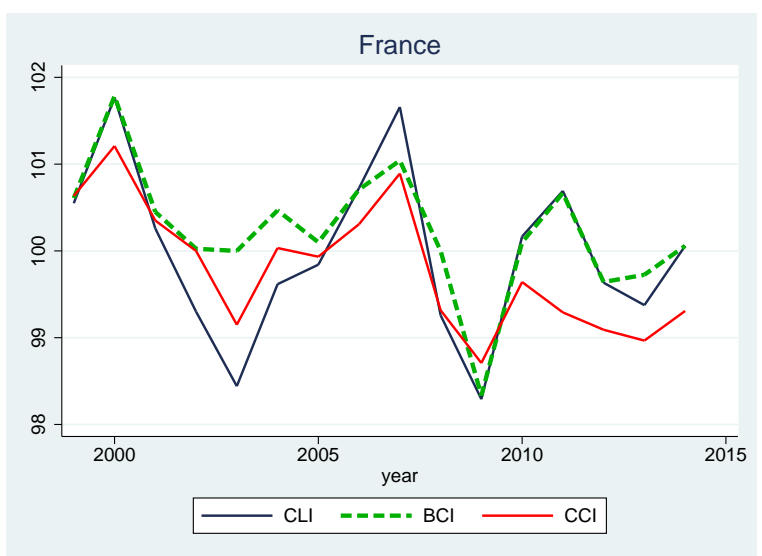

(e) France Sentiment Indicators

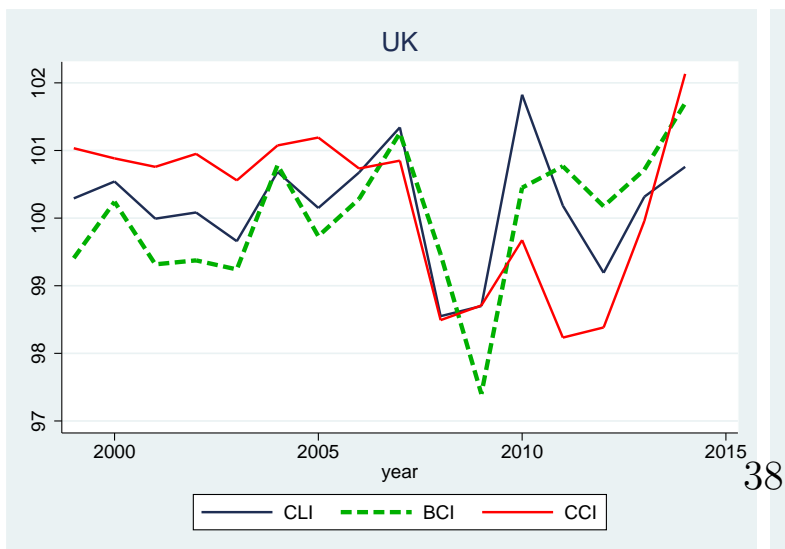

(g) UK Sentiment Indicators

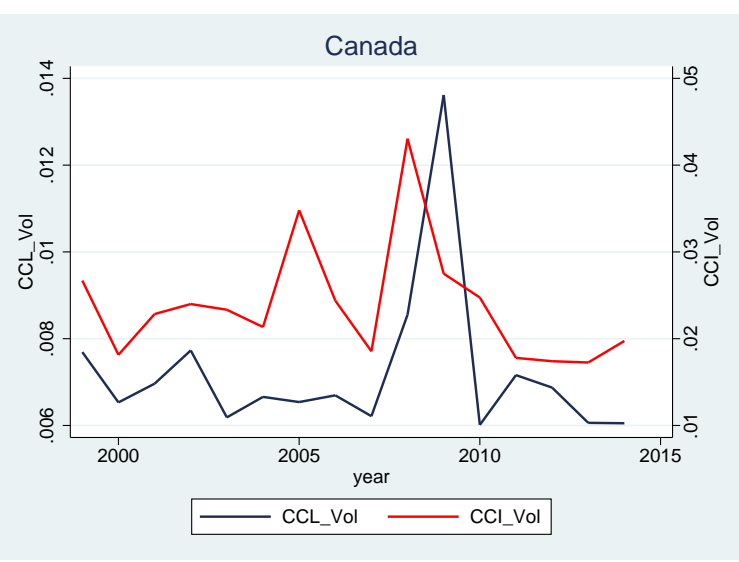

(b) Canada Sentiment Volatilities

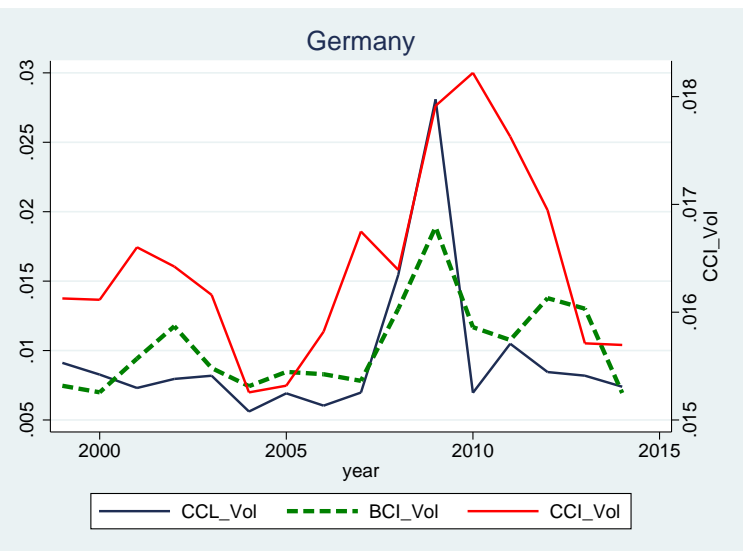

(d) Germany Sentiment Volatilities

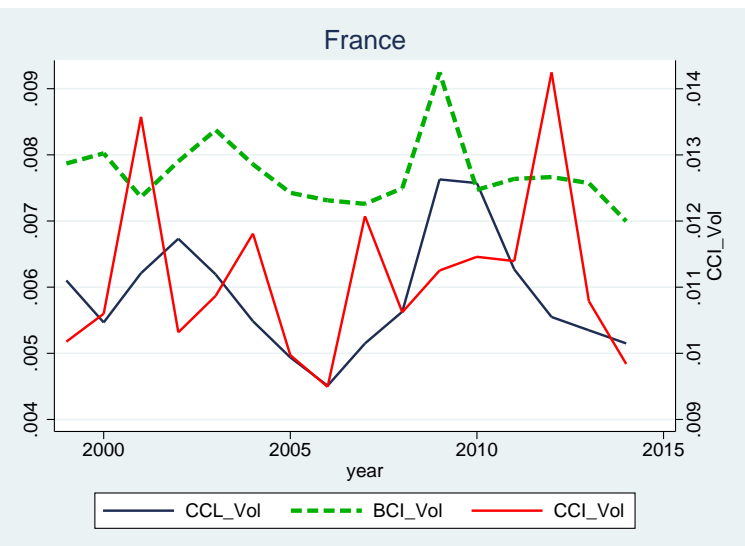

(f) France Sentiment Volatilities

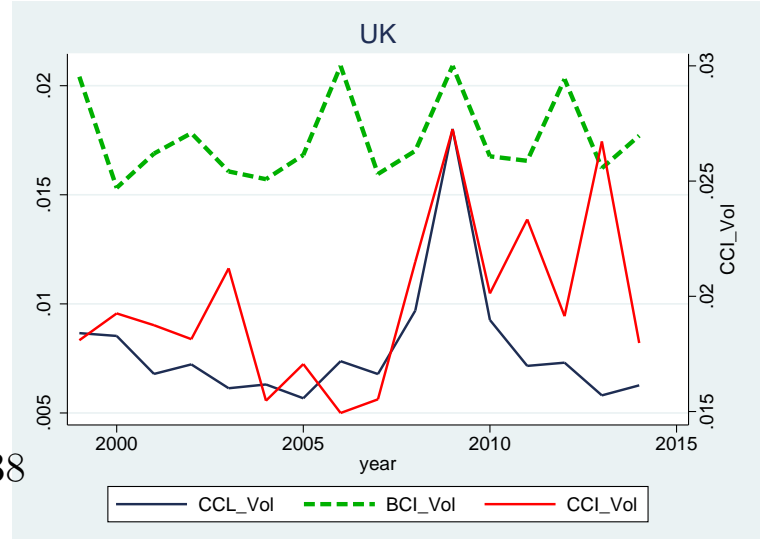

(h) UK Sentiment Volatilities

Figure 1: The level of sentiments and their volatility 


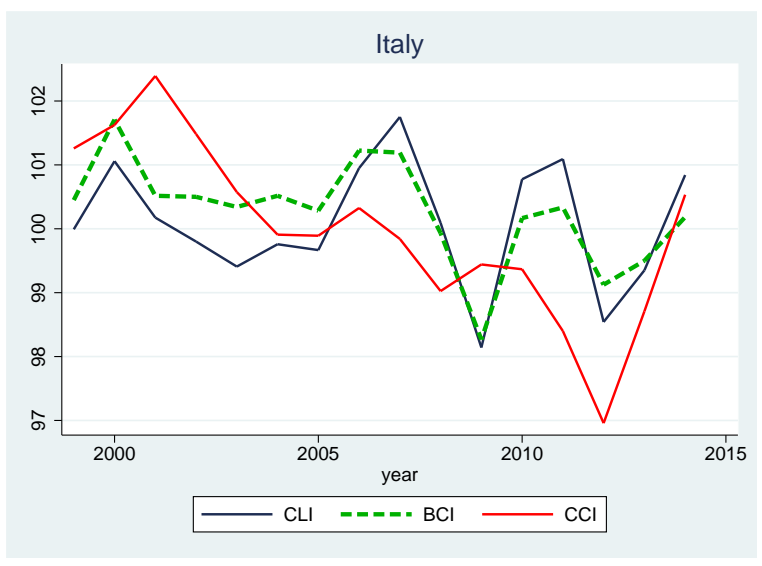

(i) Italy Sentiment Indicators

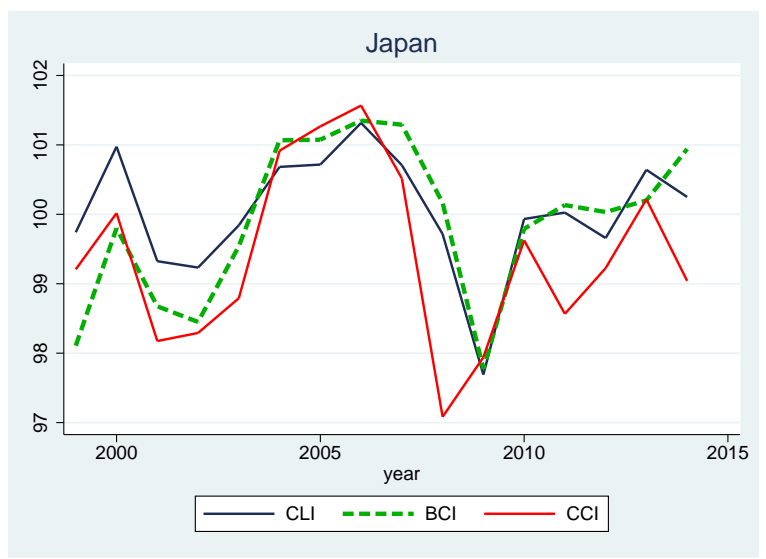

(k) Japan Sentiment Indicators

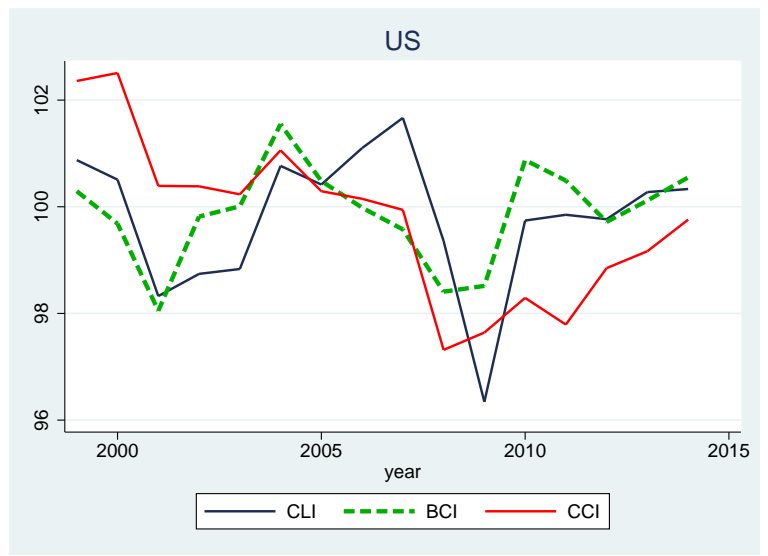

(m) US Sentiment Indicators

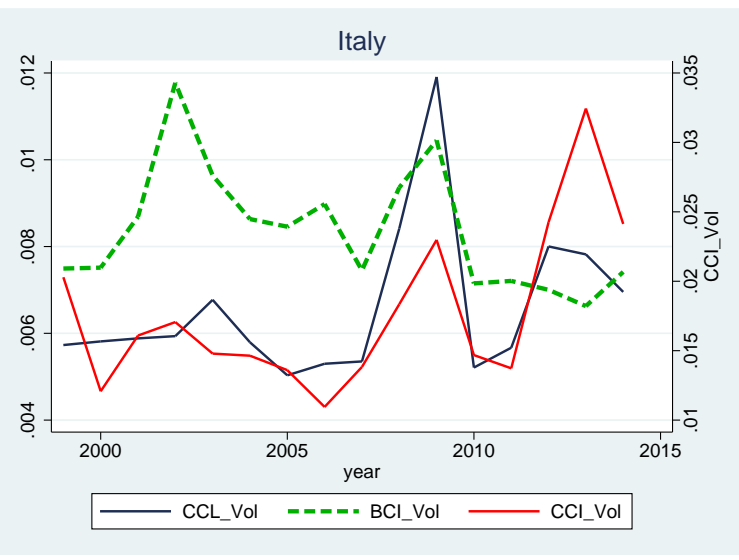

(j) Italy Sentiment Volatilities

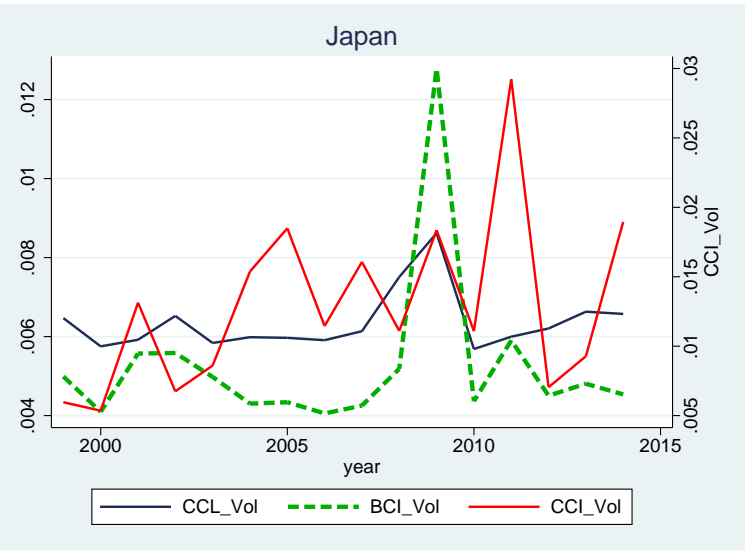

(1) Japan Sentiment Volatilities

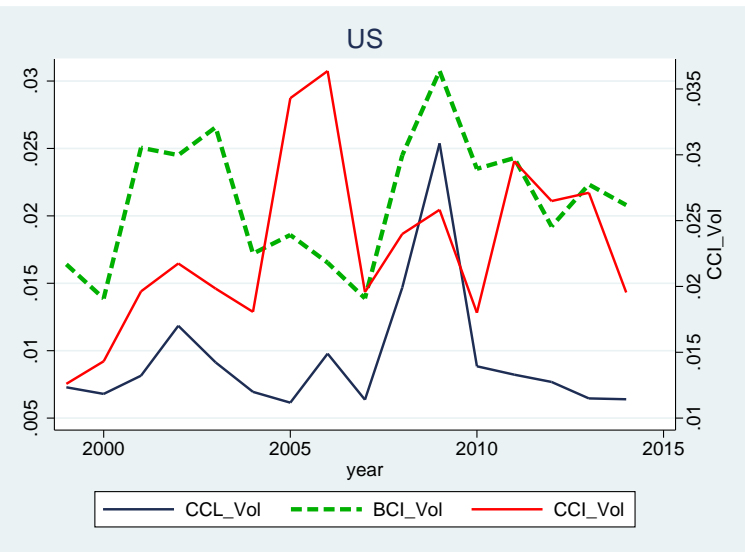

(n) US Sentiment Volatilities

Figure 1: The level of sentiments and their volatility 

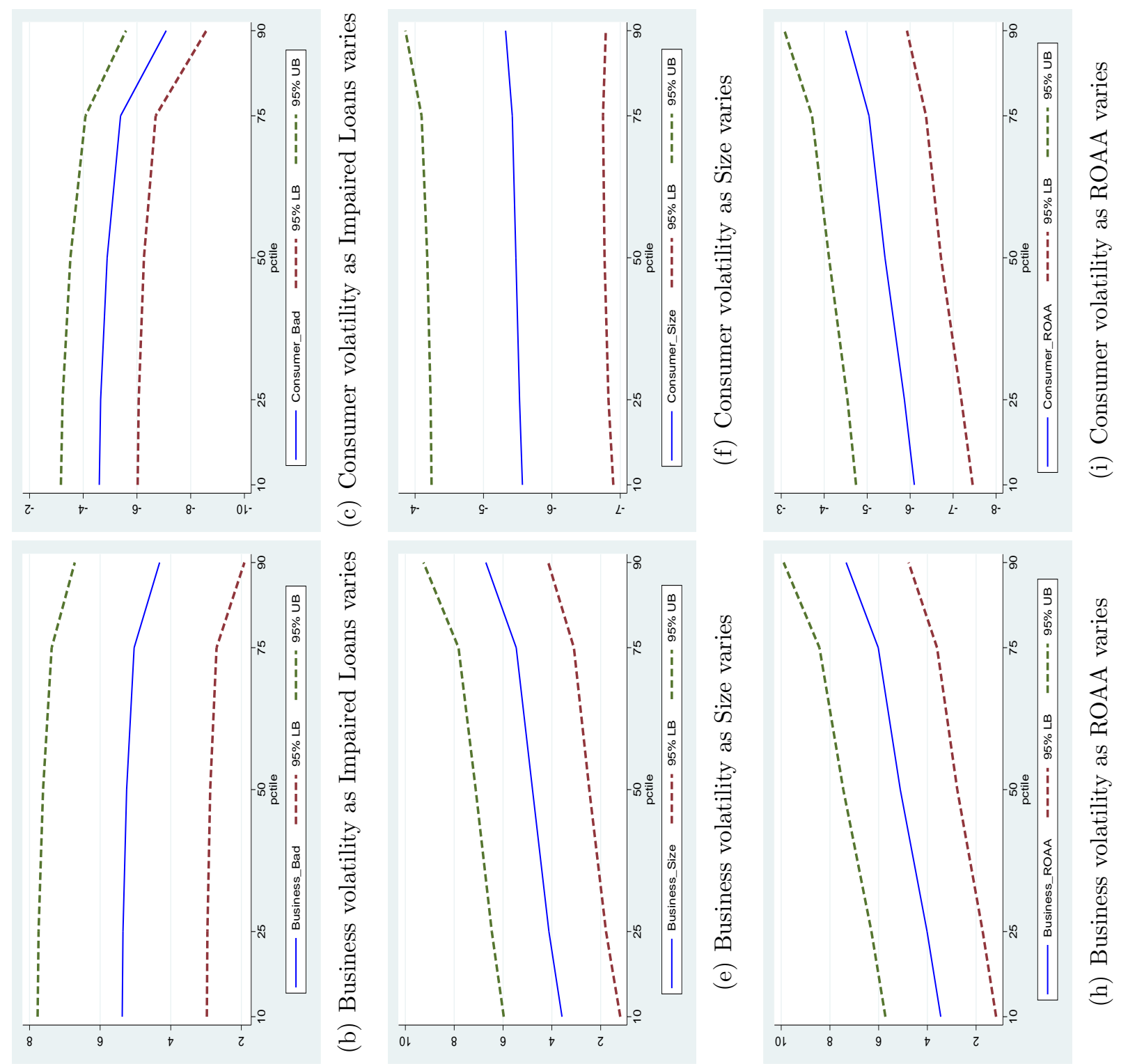

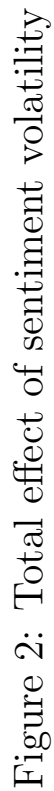
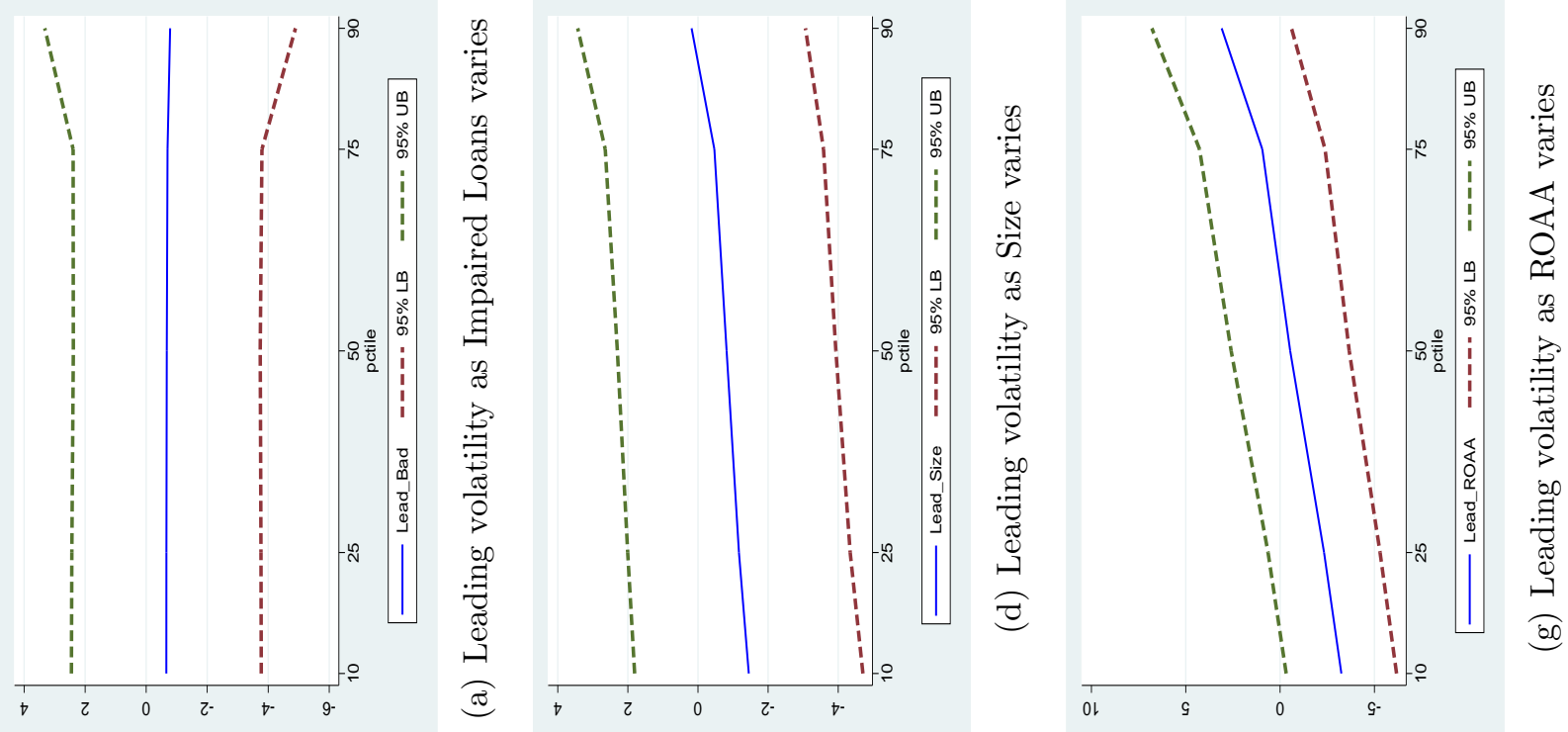


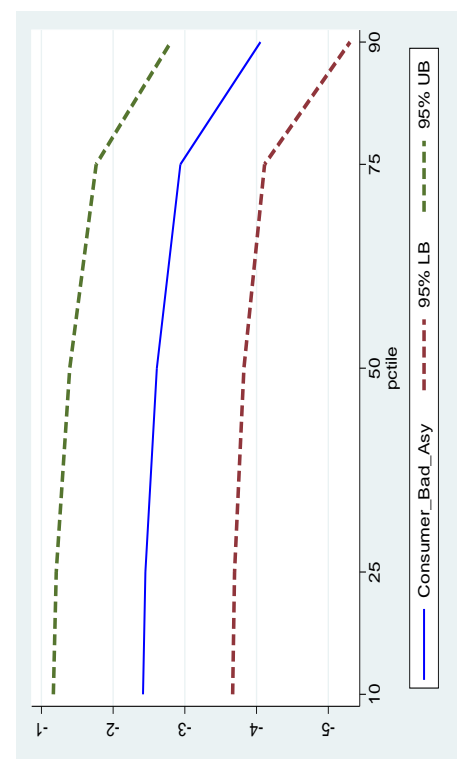

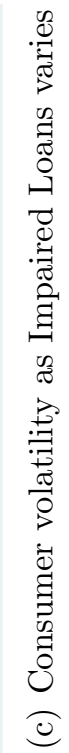
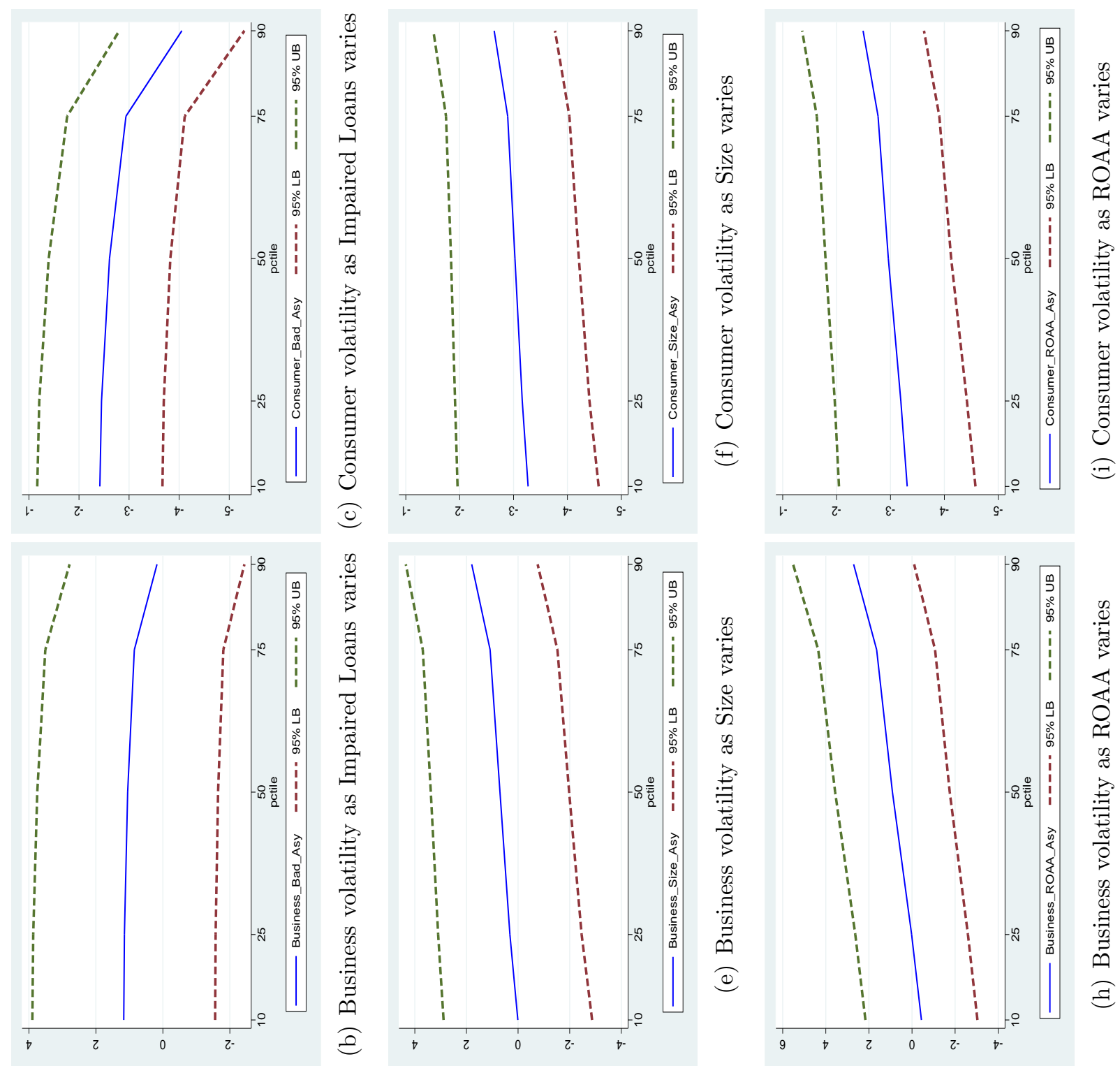

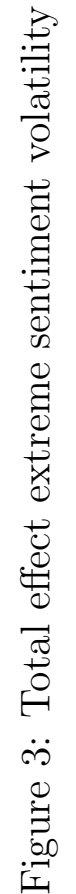
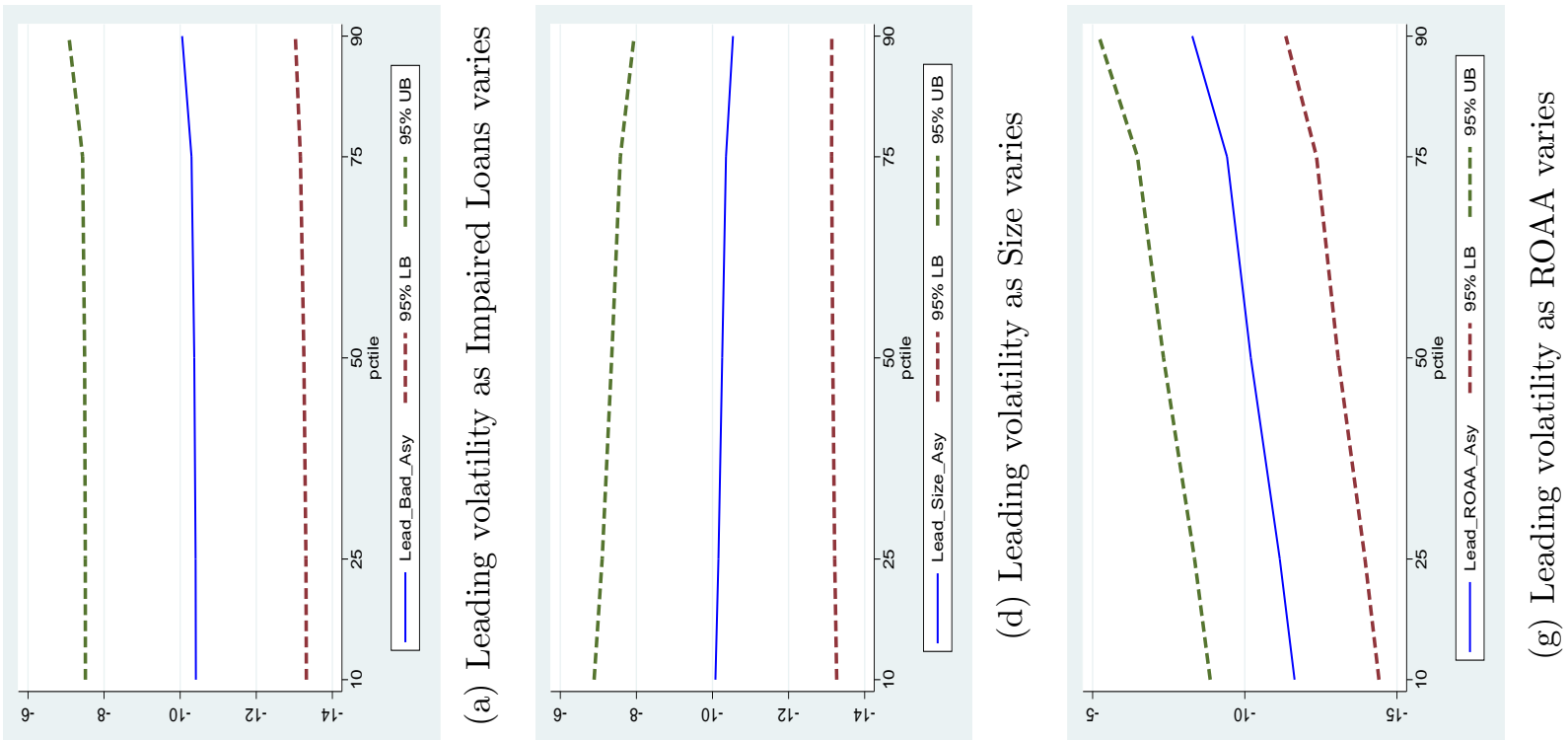